\title{
A hoard of astragals discovered in the Copper Age settlement at lepureşti, Giurgiu County, Romania
}

\author{
Raluca Kogălniceanu 1, Ana Ilie 2, Monica Mărgărit3, Angela Simalcsik4 \\ and Valentin Dumitraşcu 5 \\ 1 "Teohari Antonescu" County Museum, Giurgiu, RO \\ raluca.kogalniceanu@gmail.com \\ 2 "Princiary Court" Museum Complex, Târgovişte, RO; ana_arheo@yahoo.com \\ 3 Valahia University, Târgovişte, RO; monicamargarit@yahoo.com \\ 4 Centre of Anthropology, Romanian Academy - laşi branch, RO; angellisimal@yahoo.com \\ 5 "Vasile Pârvan" Institute of Archaeology, Bucharest, RO; validumitrascu@yahoo.com
}

\begin{abstract}
This article presents the discovery of 25 abraded and perforated ovicaprid astragals in a burned house at the Gumelnita Copper Age settlement at Iepurești in Southern Romania. They were analysed in terms of their processing, of the taphonomic processes that affected them (burning), and of their spatial distribution. These astragals were also analysed in the wider context of more or less similar discoveries made mainly south and east of the Carpathian Mountains, in Romania, but also south of the Danube, in Bulgaria.
\end{abstract}

IZVLEČEK - V članku predstavljamo odkritje 25 odrgnjenih in preluknjanih gležnjic/astragalov ovce/ koze v požgani hiši na bakrenodobni naselbini kulture Gumelnita pri kraju Lepuresti v južni Romuniji. Preučili smo obdelavo, tafonomske procese (žganje) in prostorsko razporeditev teh najdb. Gležnjice/astragale smo preučevali tudi v širšem kontekstu bolj ali manj podobnih najdb, ki so jih izdelovali v glavnem južno in vzhodno od Karpatov v Romuniji, a tudi južno od Donave v Bolgariji.

KEY WORDS - abraded and perforated astragals; Copper Age; Gumelnita settlement; spatial analysis; contextual analysis

\section{Introduction}

The Iepuressti site is located in Southern Romania, approx. $30 \mathrm{~km}$ southwest of Bucharest, between the villages of Stâlpu and Iepuressti, Giurgiu County, at an altitude of approx. $65 \mathrm{~m}$ (altimetric reference system - Baltic Sea) (Fig. 1). It is located on the middle course of the Neajlov River, on its flood plain. Today, the river flows approx. 500m north of the site, but is very active, changing its course every three or four years (Ilie 2011.38). It is quite possible that the site was located on its banks in the past (Morintz 2011).

The archaeological investigations at this site began in 2007 and continued each year, expanding outside the site, in its immediate surroundings (Schuster et al. 2009; 2010; 2011; 2012; Markussen, Vornicu
2011; Kogălniceanu et al. 2012). Four sections (4 x $4 \mathrm{~m}$ ) were opened on the northern margin of the site in order to establish the stratigraphy. The research was extended into the meadow with a trench of 11 $\mathrm{x} 1.5 \mathrm{~m}$ in order to identify a possible defense system. The $2 \mathrm{x} 1 \mathrm{~m}$ test pits around the site following magnetic surveys were aimed at understanding the use of space outside the settlement.

Although the investigations in the four sections mentioned above have not been completed, we can assert that the site is the result of prehistoric human activities. The first layer (the most important in terms of the archaeological features investigated: houses, debris areas, etc.) is attributed to the Gumelniţa - Kodjadermen - Karanovo VI cultural complex 
(hereafter: G-K-KVI). The second layer was represented by a series of pits, attributed to the Early Bronze Age Glina culture.

The G-K-KVI cultural complex is known for tell settlements with several layers of habitation and was important for the production and circulation of large copper and gold artefacts. Chronologically, it evolved between 4600 and 3900 calBC (Bem 2001b; Reingruber, Thissen 2009; Brehard, Bălăşescu 2012. 3169). Although, based on pottery styles, the existence of regional expects and internal modifications is accepted (three evolution phases have been distinguished), much is still unknown about the social and territorial organisation of these communities due to the state of field research and published results.

The site is located on a levee and has the appearance of a small mound (Fig. 2), a characteristic common to a large number of G-K-KVI sites on the Găvanu-Burdea Plain considered to be tell settlements (Andreescu, Mirea 2008; Bem et al. 2001; Ilie 2011). In spite of this, the stratigraphy of this site is different from that of the tells located along the Danube (Olteniţa, Căscioarele, Pietrele, Ruse, Hârşo$\mathrm{va}$, Borduşani) which are characterised by important depositions that vary between $3-12 \mathrm{~m}$ of the habitation layers, and also from that of the tells on the Găvanu-Burdea Plain. The ongoing research at the G-K-KVI sites in the Bucşani and Vitănești-Lăceni micro areas (Haită 2001a; 2001b) suggests a different type of behaviour, the sites being formed by multiple settlements in the same place interposed by alluvial levels which mark periods of abandonment.

In this context, the excavations at Iepureşti diversify the image of this period concerning the habitation types of Gumelniţa communities on this plain north of the Danube. The discovery in the last four years of excavation (2010-2013) of 25 astragals (see Tab. 1 and Figs. 3-4) in the G-K-KVI layer must be regarded as diversifying our understanding of social organisation, both through the type of site and through the types of artefacts specific to certain types of site. The finds come from at least 13 individuals of Ovis aries or Capra hircus and underwent modifications consisting of drilling, abrading and burning.

\section{Morphology and modifications of the finds}

The astragal is a short, compact bone located in the ankle joint. The family Bovidae (including sheep and goat) has a distinctive astragal with a doublepulley at the extremities and four distinct facets. It

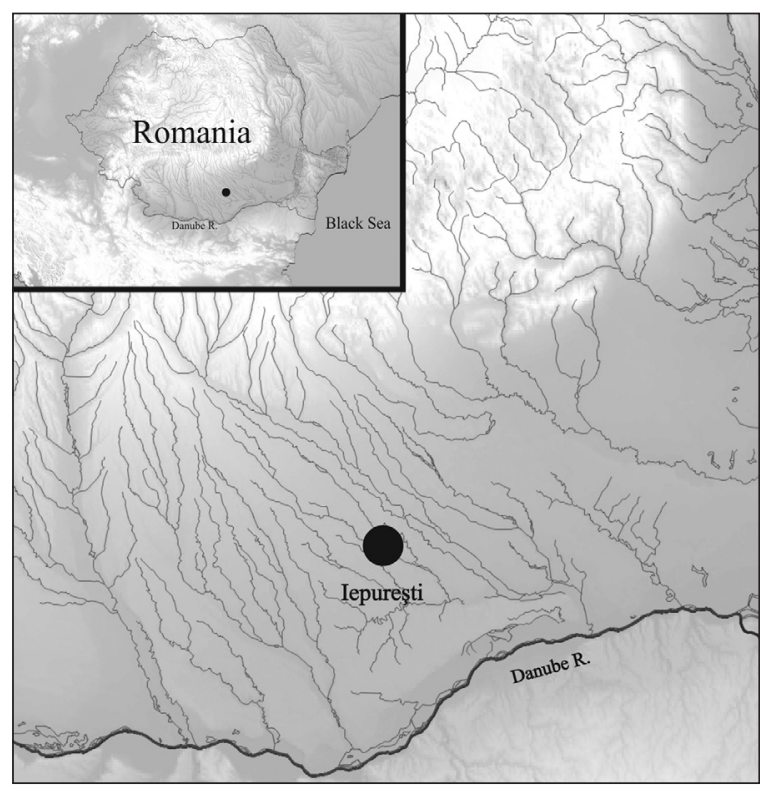

Fig. 1. Location of the site.

has a characteristic shape (cube-like) with four sides and a depression on the dorsal surface (Fig. 5). The astragal ossifies relatively early in the maturation process, making it difficult to distinguish between sub-adult and adult animals. The only indicator of age is the porosity of the bone surface observable in very young individuals (Reitz, Wing 2008).

The 25 sheep/goat astragals, complete (17) or fragmentary (8), are extremely burned (Fig. 6a, e, i), and vary in colour, from black to white, except for two examples (Tab. 2). In order to modify the anatomical morphology, the astragals were abraded on the four sides, which helped to reduce the protuberances specific to this type of bone, which finally gave the pieces an approximately rectangular form (Fig. $6 \mathrm{~b}, \mathrm{~d}, \mathrm{~g}, \mathrm{~h}, \mathrm{j}, \mathrm{l})$. A perforation was made in the centre by boring alternately from each side. The dimensions are uniform, being determined both by the selection of a single species, and by the similar processing technique (see Tab. 2).

At the beginning of our analysis, we started, $a$ priori, from several assumptions concerning the technique used to make these pieces. These suppositions were later confirmed or disproved by microscopic study. The plantar side of all the examples was abraded, acquiring a perfectly flat aspect, unlike the dorsal, lateral and medial sides, whose morphology was modified to varying degrees. The abrasion scratches are oblique to the axis of the piece and parallel with each other, but are hard to detect even at a magnification of 200x due to the deterioration of the surface caused by burning. We supposed that the 
rectilinear edges might have been created through previous processing (e.g., cutting by sawing) but we have not been able to identify any marks of this nature. Our conclusion is that they were transformed exclusively through an abrasive action of linear friction.

Other observations were formulated regarding the central perforations made, with just one exception, at the level of

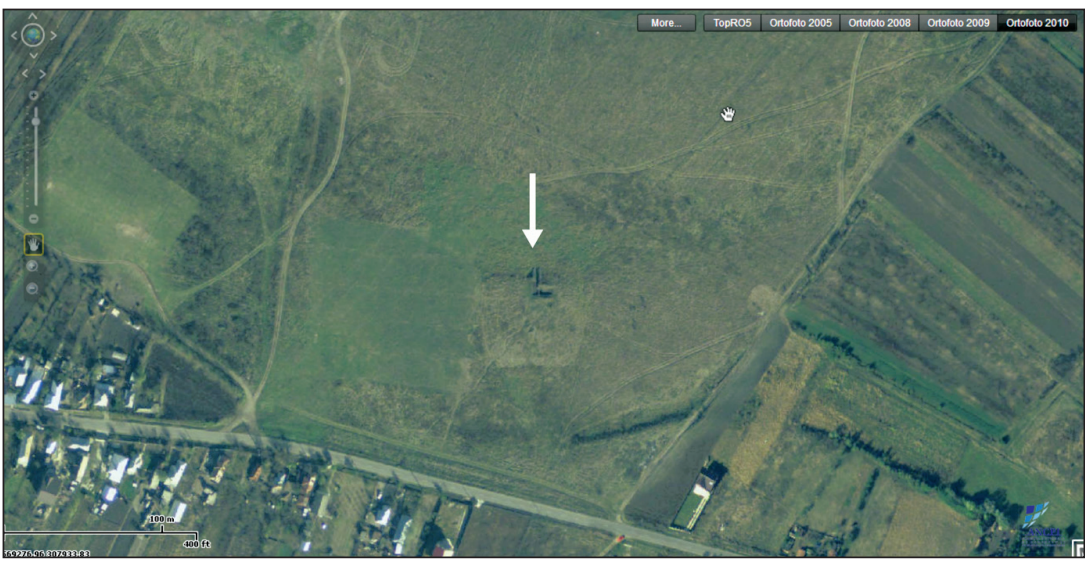

Fig. 2. Aerial image of the site (image from ANCPI).

A general observation is that the astragals were burned in a dry state, and that the burning was uneven. The analysed pieces are not deformed or contracted; there are no fissures deep in the bone; they are not white-coated, and the colour inside the bone is yellow-brownish.

The bone wall displays a variety of colours (according to the RGB scale), varying from dark brown tion in two stages, i.e the piece might have been used as a polisher in an abrading action on a highly abrasive surface (ceramics, perhaps), using a new side as the different faces were worn out, until their final exhaustion (until the piece could not be held for abrading). During a second stage, the piece might have been perforated and converted into a bead, part of a necklace. Yet again, an examination by microscope showed that the abrasion followed the perforation, as it had destroyed its edges, and also that the pieces were suspended for a long time on a thread, as the scratches from the perforation process have been preserved in only a few cases (Fig. 6c, f, k). The conclusion is that, regardless of the function they had, the items were perforated at the beginning of the process of technological transformation.

Concerning the burning of the astragals, the criteria used for analysis were as follows:

- the colour of the exterior surface of the bone;

- the pattern of cracking of the external bone;

- the presence/absence of warping.

\begin{tabular}{|lcccccc|}
\hline No. & $\begin{array}{c}\text { Piece } \\
\text { no. }\end{array}$ & $\begin{array}{c}\text { Year of } \\
\text { discovery }\end{array}$ & Section & Square & $\begin{array}{c}\text { Depth (m) } \\
\text { (in relation to } \\
\text { a 'o' point) }\end{array}$ & Side \\
\hline 1 & 373 & 2010 & S2 & C3 & -1.13 & $\mathrm{R}$ \\
2 & 396 & 2010 & S2 & C3 & -1.01 & $\mathrm{~L}$ \\
3 & 404 & 2010 & S2 & B4 & -1.18 & $\mathrm{R}$ \\
4 & 408 & 2010 & S2 & A-D/3-4 & $-0.90-1.10$ & $\mathrm{R}$ \\
5 & 422 & 2011 & $\mathrm{~S} 2$ & $\mathrm{~B} 4$ & -0.96 & $\mathrm{~L}$ \\
6 & 423 & 2011 & $\mathrm{~S} 2$ & $\mathrm{~B} 4$ & -0.96 & $\mathrm{~L}$ \\
7 & 424 & 2011 & $\mathrm{~S} 2$ & $\mathrm{~B} 4$ & -0.96 & $\mathrm{~L}$ \\
8 & 425 & 2011 & $\mathrm{~S} 2$ & $\mathrm{~B} 4$ & -0.96 & $\mathrm{R}$ \\
9 & 428 & 2011 & $\mathrm{~S} 2$ & $\mathrm{C} 4$ & -0.98 & $\mathrm{~L}$ \\
10 & 430 & 2011 & $\mathrm{~S} 2$ & $\mathrm{~B} 3$ & -1.08 & $\mathrm{~L}$ \\
11 & 431 & 2011 & $\mathrm{~S} 2$ & $\mathrm{~B} 4$ & -1.07 & $\mathrm{R}$ \\
12 & 432 & 2011 & $\mathrm{~S} 2$ & $\mathrm{~B} 4$ & -1.18 & $\mathrm{R}$ \\
13 & 433 & 2011 & $\mathrm{~S} 2$ & $\mathrm{C} 4$ & -1.18 & $\mathrm{R}$ \\
14 & 437 & 2011 & $\mathrm{~S} 2$ & $\mathrm{~B} 3$ & -1.03 & $\mathrm{~L}$ \\
15 & 439 & 2011 & $\mathrm{~S} 2$ & $\mathrm{~B} 4$ & -1.09 & $\mathrm{R}$ \\
16 & 441 & 2011 & $\mathrm{~S} 2$ & $\mathrm{~B} 4$ & -1.09 & $\mathrm{~L}$ \\
17 & 486 & 2011 & $\mathrm{~S} 2$ & $\mathrm{~B} 4$ & -1.19 & $\mathrm{R}$ \\
18 & 489 & 2011 & $\mathrm{~S} 2$ & $\mathrm{~B} 4$ & -1.19 & $\mathrm{~L}$ \\
19 & 490 & 2011 & $\mathrm{~S} 2$ & $\mathrm{C} 4$ & -1.17 & $\mathrm{~L}$ \\
20 & 560 & 2011 & $\mathrm{~S} 2$ & $\mathrm{~A}-\mathrm{D} / 3-4$ & - & $\mathrm{R}$ \\
21 & 562 & 2012 & $\mathrm{~S} 2$ & $\mathrm{~A}-\mathrm{D} / 3-4$ & - & $\mathrm{L}$ \\
22 & 638 & 2012 & $\mathrm{~S} 2$ & $\mathrm{C} 3$ & -1.26 & $\mathrm{~L}$ \\
23 & 690 & 2012 & $\mathrm{~S} 2$ & $\mathrm{C} 4$ & -1.29 & $\mathrm{R}$ \\
24 & 751 & 2013 & $\mathrm{~S} 2$ & $\mathrm{~A} 4$ & -1.47 & $\mathrm{~L}$ \\
25 & 753 & 2013 & $\mathrm{~S} 2$ & $\mathrm{~A} 4$ & -1.48 & $\mathrm{R}$ \\
\hline
\end{tabular}

Tab. 1. List of discovered astragals, indicating the year of discovery, the location within the excavation, the depth and whether they were left or right side. 
$\left(200^{\circ} \mathrm{C}\right)$ through black $\left(300^{\circ} \mathrm{C}\right)$ and grey-brown $\left(400^{\circ} \mathrm{C}\right)$ to light brown $\left(500^{\circ} \mathrm{C}\right)$, dark grey $\left(600^{\circ} \mathrm{C}\right)$ and light grey $\left(700^{\circ} \mathrm{C}\right)$. In two cases a temperature of $800^{\circ} \mathrm{C}$ (dark beige) and even $900^{\circ} \mathrm{C}$ (light beige) were reached (these values are on the threshold of calcination). In conclusion, the burning temperature can be ascribed to an interval between $200^{\circ} \mathrm{C}$ and $700^{\circ} \mathrm{C}$ (Walker et al. 2008). In ten cases, the temperature did not exceed $400-500^{\circ} \mathrm{C}$ (nos. 373,396 , 404, 431, 433, 437, 489, 490, 562, and 690) (Fig. $7 a)$. In another eleven cases (nos. 422, 423, 424, $425,428,430,432,439,441,486$, and 560), the temperature reached $600-700^{\circ} \mathrm{C}$ (Fig. $7 \mathrm{~b}$ ). The bone wall indicates higher temperatures, of $800-900^{\circ} \mathrm{C}$, in two cases (nos. 638 and 408), where the presence of whitish areas indicates temperatures close to those required for calcination (Fig. 7c).

There is one additional observation concerning astragal no. 408. This fragment, unlike the others, seems to have undergone uniform burning. It appears whitecoated, meaning that there is a whitewash layer of

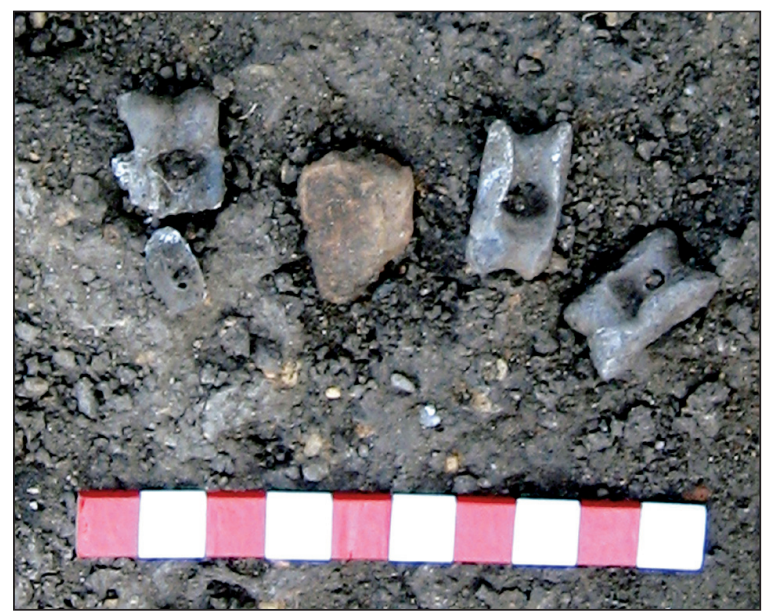

Fig. 3. Image of astragals in situ.

approx. $1 \mathrm{~mm}$ that 'coats' the rest of the dark-coloured bone tissue. In addition, the external surface is dotted with quite deep fissures that form a network. All these traits are characteristic of burning of fleshed or recently de-fleshed remains ('green' bones). Nonetheless, we remain reserved concerning the

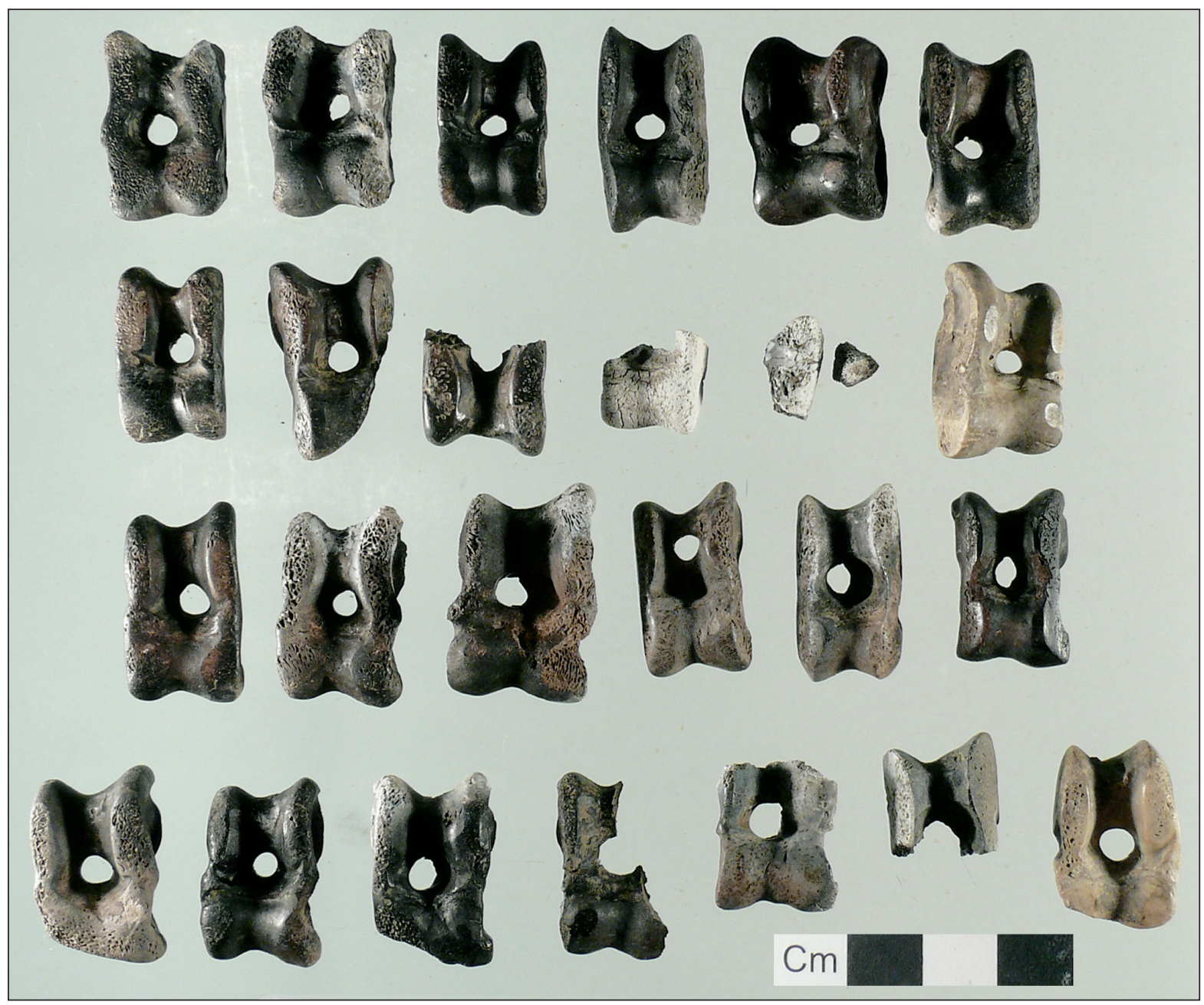

Fig. 4. All 25 astragals found in Section 2. 
state of bone at the time of burning because there is only half of it present in the sample.

Cracks were recorded in nine out of 25 astragals (nos. 373, 408, 422, 424, 437, 490, 560, 638, and 690). The pattern of cracks is not uniform (as it usually is on long bones), but appears as a network (similar to the patterns that would appear on cranial vault bones). With the exception of astragal no. 408, which has both surface and profound cracks (Fig. $8 a)$, in all the other cases the cracks are superficial (Fig. $8 \mathrm{~b}$ ), i.e. they extend for a maximum of $1 \mathrm{~mm}$ into the bone tissue (although they are visible to the naked eye). Only two astragals (nos. 751 and 753) of the 25 appear to be unburned. In these two cases, the colour of the external bone wall is not typical of unburned (animal or human) bone: while bone that is not touched by flames would generally be reddish or reddish-beige, the astragals nos. 751 and 753 are greyish-beige (Fig. 9). It is possible that these astragals were close to a heat source, but were not been touched directly by the flames.

\section{Context of discovery}

Due to the location of the site in the flood plain of the Neajlov River, the archaeological layers underwent significant pedogenetic degradation, which makes the reading of traces of Chalcolithic human activity difficult. The 23 burned astragals, as well as the two unburned ones, were not found in a vessel or assembled in a more restricted area, but dispersed over an area of $2.5 \mathrm{~m}^{2}$, and at different depths. We tried to analyse the characteristics of their dispersal and to answer several other questions to determine if they were part of a hoard.

\begin{tabular}{|c|c|c|c|c|c|c|c|c|c|c|c|}
\hline \multirow[b]{2}{*}{ 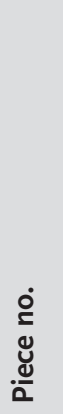 } & \multicolumn{4}{|c|}{ Abrasion } & \multicolumn{2}{|c|}{ Perforation } & \multicolumn{4}{|c|}{ Morphometry } & \multirow[b]{2}{*}{ Observations } \\
\hline & $\frac{\frac{0}{0}}{\frac{\pi}{n}}$ & $\begin{array}{l}\frac{0}{n} \\
\frac{0}{n} \\
\frac{\pi}{\pi} \\
\frac{\pi}{\alpha}\end{array}$ & $\frac{\frac{0}{0}}{\frac{\pi}{n}}$ & 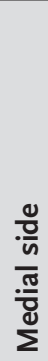 & 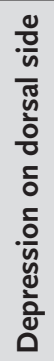 & 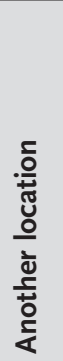 & 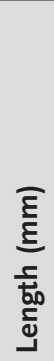 & 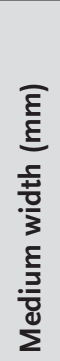 & 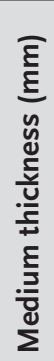 & 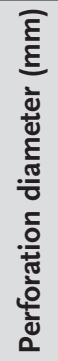 & \\
\hline 373 & $x$ & $\mathrm{x}$ & $x$ & $\mathrm{x}$ & $x$ & & 23 & 14 & 8 & 5 & Complete, burned \\
\hline 396 & $x$ & $\mathrm{x}$ & $\mathrm{x}$ & $x$ & $x$ & & \multicolumn{4}{|c|}{ indet. } & Fractured, burned \\
\hline 404 & $x$ & $\mathrm{x}$ & $x$ & $x$ & $x$ & & 27 & 16 & 9 & 5 & Fractured obliquely, burned \\
\hline 408 & $x$ & $\mathrm{x}$ & $\mathrm{x}$ & $x$ & $x$ & & \multicolumn{4}{|c|}{ indet. } & Fragment, burned \\
\hline 422 & $x$ & $\mathrm{x}$ & $x$ & $x$ & & $x$ & 25 & 13 & 7 & 4 & Complete, burned \\
\hline 423 & $x$ & $\mathrm{x}$ & $\mathrm{x}$ & $\mathrm{x}$ & $x$ & & 26 & 14 & 8 & 5 & Complete, burned \\
\hline 424 & $x$ & $\mathrm{x}$ & $x$ & $x$ & $x$ & & - & 15 & 9 & 5 & Fractured, burned \\
\hline 425 & - & - & - & - & - & & \multicolumn{4}{|c|}{ indet. } & Two small fragments, burned \\
\hline 428 & $x$ & $\mathrm{x}$ & $\mathrm{x}$ & $x$ & $x$ & & 25 & 15 & 8 & 5 & Complete, burned \\
\hline 430 & $x$ & $\mathrm{x}$ & $x$ & $x$ & $x$ & & 27 & 16 & 7 & 4 & Complete, burned \\
\hline 431 & $x$ & $\mathrm{x}$ & $\mathrm{x}$ & $x$ & $x$ & & 24 & 14 & 9 & 4 & Complete, burned \\
\hline 432 & $x$ & $\mathrm{x}$ & $\mathrm{x}$ & $\mathrm{x}$ & $\mathrm{x}$ & & 26 & 16 & 9 & 4 & Complete, burned \\
\hline 433 & $x$ & $x$ & $x$ & $x$ & $x$ & & 25 & 17 & 11 & 4 & Complete, burned \\
\hline 437 & $x$ & $x$ & $x$ & $x$ & $x$ & & 25 & 17 & 9 & 4 & Complete, burned \\
\hline 439 & $x$ & $\mathrm{x}$ & $x$ & $x$ & $x$ & & 28 & 14 & 8 & 4 & Complete, burned \\
\hline 441 & $x$ & $x$ & $x$ & $x$ & $x$ & & 29 & 19 & 9 & 5 & Complete, burned \\
\hline 486 & $x$ & $x$ & $x$ & $x$ & $x$ & & 26 & 15 & 7 & 5 & Complete, burned \\
\hline 489 & $x$ & $x$ & $x$ & $x$ & $x$ & & 24 & 15 & 8 & 4 & Complete, burned \\
\hline 490 & $x$ & $\mathrm{x}$ & $\mathrm{x}$ & $\mathrm{x}$ & $x$ & & 27 & 16 & 6 & 4 & Complete, burned \\
\hline 560 & $x$ & $x$ & $x$ & $x$ & $x$ & & 26 & 15 & 9 & 5 & Complete, burned \\
\hline 638 & $x$ & $x$ & $x$ & $x$ & $x$ & & 35 & 16 & 11 & 4 & Slightly fractured, burned \\
\hline 690 & $x$ & $x$ & $x$ & $x$ & $x$ & & - & 16 & 7 & - & Fractured, burned \\
\hline 562 & $x$ & $x$ & $x$ & $x$ & $x$ & & - & 15 & 8 & - & Fractured, burned \\
\hline 751 & $x$ & $\mathrm{x}$ & $x$ & $x$ & $x$ & & 25 & 16 & 7 & 4 & Complete, unburned \\
\hline 753 & $x$ & $\mathrm{x}$ & & $x$ & $x$ & & 25 & 16 & 10 & 3.5 & Complete, unburned \\
\hline
\end{tabular}

Tab. 2. List of morphometric data and modifications suffered by the astragals. 
In the eastern part of section S2 (Fig. 10), although the archaeological deposits have not yet been excavated completely, two overlapping G-K-KVI features have been identified and investigated: a burned house (H4) and an area of debris beneath it.

The $\mathrm{H} 4$ house was investigated over an area of approx. $4 \mathrm{~m}^{2}$. In the field, it was identified based on the density of burned wattle and daub pieces that pigmented the area, although the dimensions of these pieces were not usually greater than $2-4 \mathrm{~cm}$. A series of vessels was found at the top of this burned and greatly degraded wattle and daub area. Based on these, the house was culturally attributed to the G-K-KVI complex. Two Early Bronze Age pits (Pit 1 and 2) had disturbed the investigated surface of the house (Fig. 17).

The thickness of the destruction of the house was approx. 15-20cm (Fig. 11). A layer characterised by an impressive quantity of pottery fragments, animal bones and even wattle and daub pieces was identified beneath it, at the same location, and starting at a depth of $-1.25 /-1.30 \mathrm{~m}$ in the uphill grid squares (B-D) and $-1.35 /-1.40 \mathrm{~m}$ in the downhill grid square (A). We considered this as representing a debris area. The two unburned astragals were found in this feature.

One question is to which feature the 23 burned astragals can be attributed: to the burned house or the debris area below it (taking into consideration the fact that there are no technological differences between the burned and unburned pieces)?

The burned astragals found in 2010 were discovered immediately below the burned vessels found in the

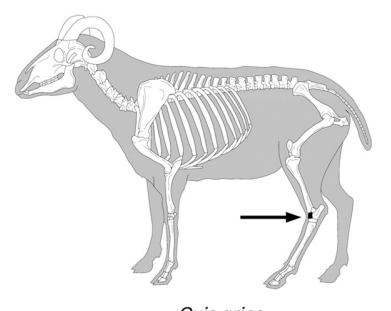

Ovis aries

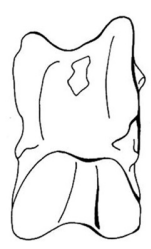

Dorsal side

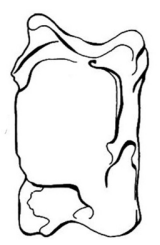

Plantar side

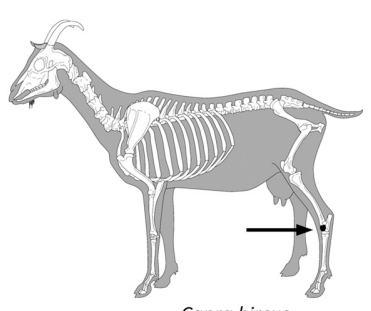

Capra hircus

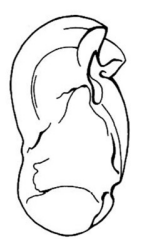

Lateral side

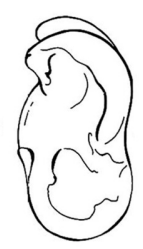

Medial side
Fig. 5. Location and morphology of the astragal. upper part of the burned wattle and daub layer of the house $\mathrm{H} 4$. The burned astragals discovered in 2011 and 2012 were found either in the reddish level interpreted as the last remains of house $\mathrm{H} 4$, and also below it, at the interface with the layer interpreted as the debris area. As a final remark on this subject, it can be said that most of the finds were located between $-0.95 \mathrm{~m}$ and $-1.20 \mathrm{~m}$ (Fig. 12).

\section{Analysis of the astragals' spatial distribution and context of discovery}

As the astragals were not found in a vessel or concentrated in a more restricted area, but were found dispersed over a $2.5 \mathrm{~m}^{2}$ area, we tried to analyse the characteristics of their dispersal, and to answer several other questions in order to determine if they are part of a hoard or not.

\section{How similar are the pieces in terms of shape, size, and how were they modified?}

From a technological perspective, all the astragals underwent the same treatment. All of them were perforated through the centre, followed by a flattening of the surface through abrasion (resulting in a rectangular section). The uniformity in terms of shape and size also derives from the source of the bones being Ovis aries or Capra hircus only. We believe that these choices in terms of technology and species are not random, and that the desired outcome was a unified ensemble, with a strong visual impact, and that they were probably kept together.

While the first two types of modification (drilling and abrasion) were intentional (at least the drilling), their burning was, we think, accidental. An argument to support this assertion is the variations in colour among the pieces and even on single pieces.

\section{What does their spatial distribution tell us?}

We looked at their spatial distribution both vertically and horizontally. From the point of view of the depth at which the astragals were discovered, we immediately noticed two anomalies (see Tab. 1; Fig. 12). Before anything else, we should draw attention to the fact that the research area lies on a slight slope from south to north, and in Section 2 the difference between the southern part (grid squares D) and the northern part (grid squares $\mathrm{A}$ ) is approx. $0.25 \mathrm{~m}$.

Although the depth mostly increased over the four years of excavations, the altitude data for the first year has bigger values than expected. This might be 
a
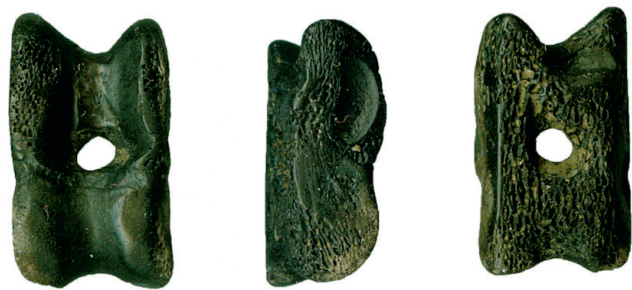

$\mathrm{cm}$
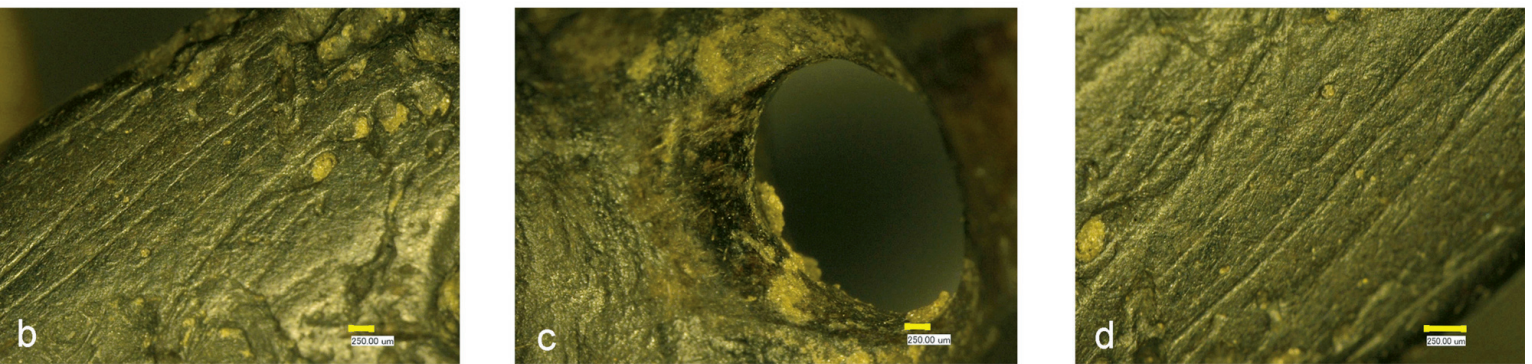

e
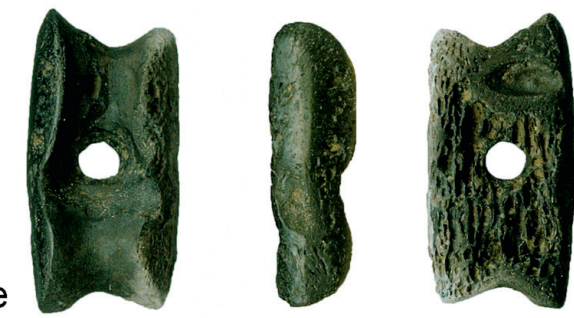

$\mathrm{cm}$
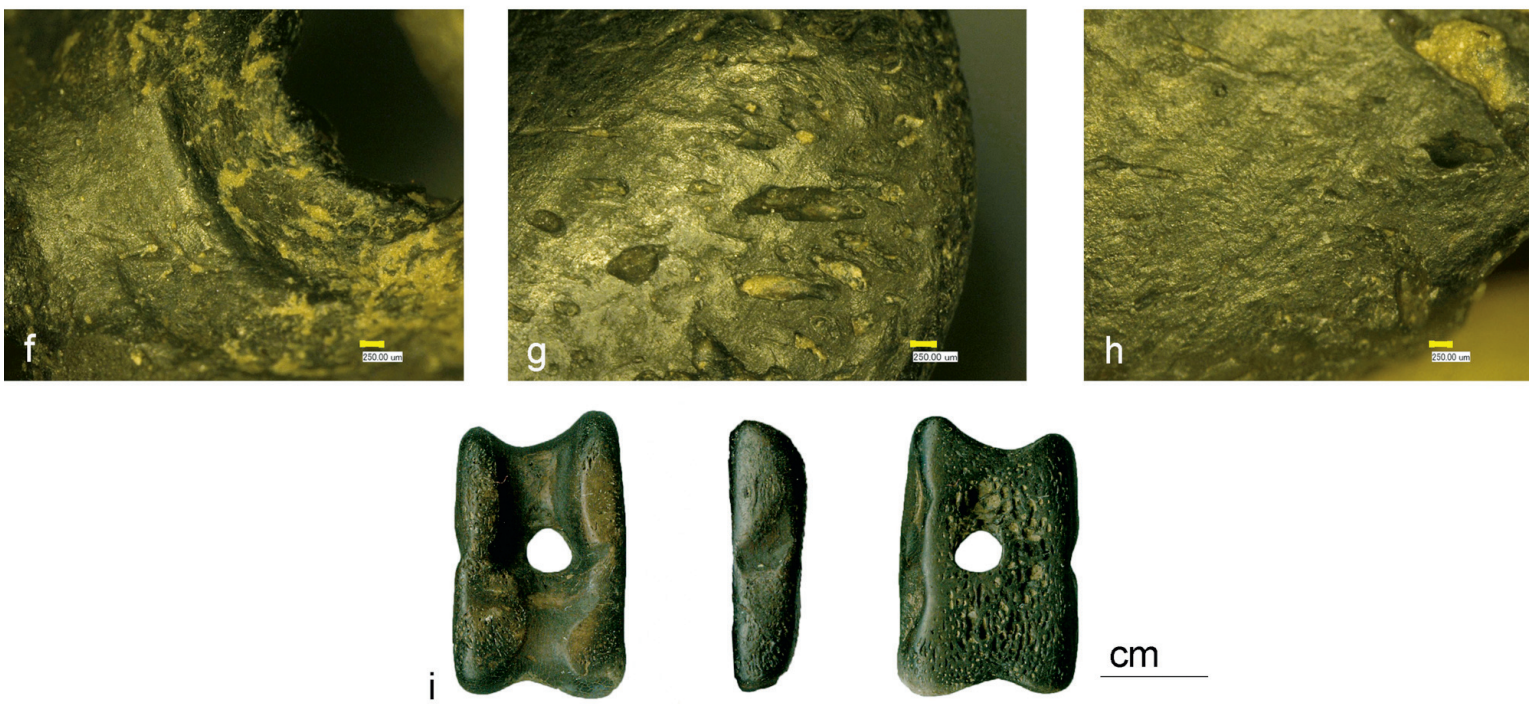

$\mathrm{cm}$
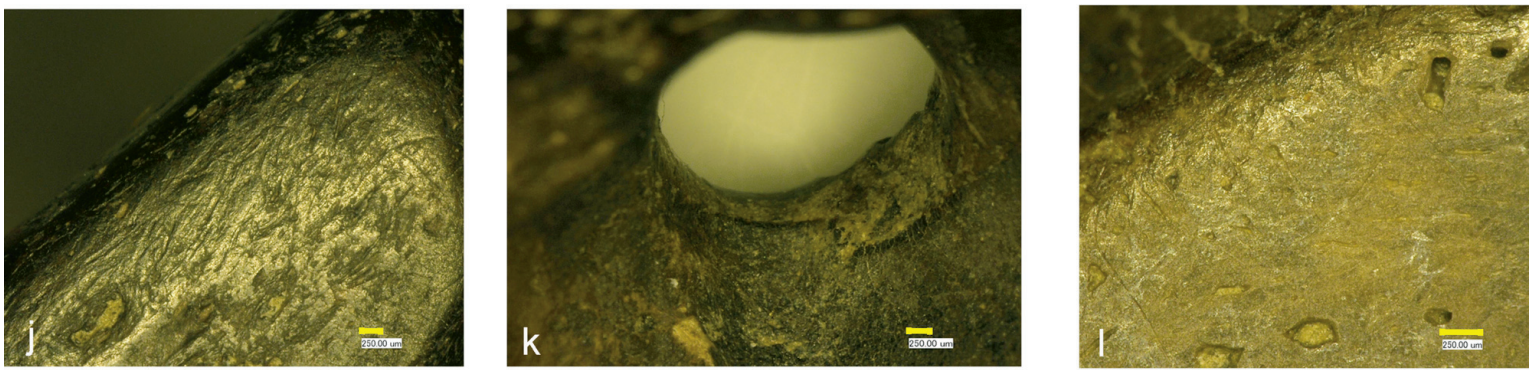

Fig. 6. a, $e, i$ - abraded and perforated astragals from the Iepuressti settlement; $b, d, g, h, j, l$ - details of the abraded surface (magnification: 50x; 100x; 50x; 75x; 50x; 100x); $c, f, k$-details of the perforation made by rotation (magnification: 50x; 50x; 50x). 

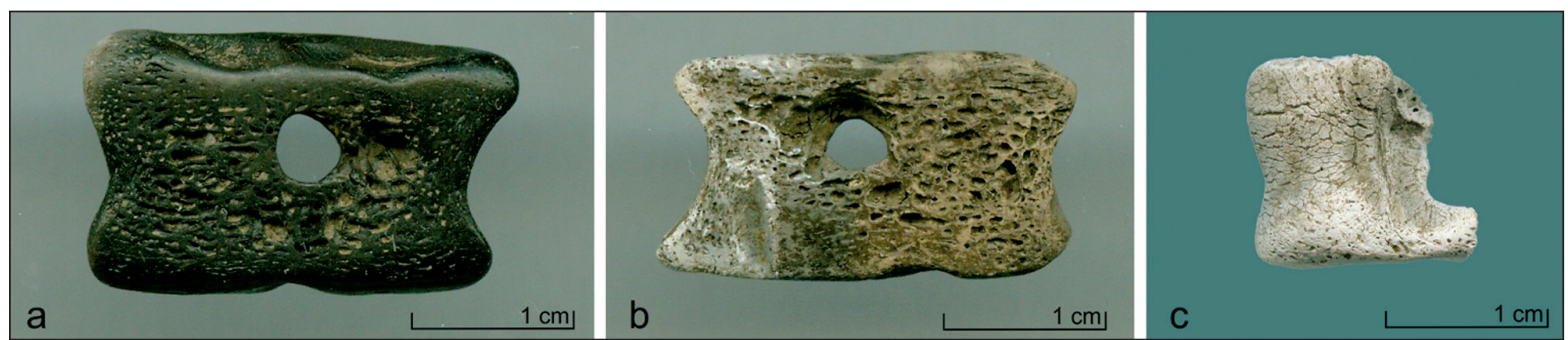

Fig. 7. Variations in the colour of the astragals.

due to the gradual erosion of the terrain at the initial point ' 0 ', which also led to the changing of its location the following year, and implicitly to a recalculation of the depths. We also noted that the depth of the last two astragals to be found appeared to be outliers in the series of data. This, together with the fact that so far they were the only unburned ones, made us question their association with the same group of astragals as the others. An argument in favor would be the fact that the astragals found during the last two years (burned and unburned), small in number and at a greater depth, are all located on the periphery of the main group. In addition, it can be seen that the house level curves downward in the area where squares A4 and B4 meet (Fig. 11), so it is not surprising that the last two astragals found precisely in that area were at a greater depth than the others. Since we do not find these arguments (depth and peripheral position) to be enough to exclude the two burned astragals from the possible hoard, they also might not constitute by themselves strong enough arguments to exclude the unburned astragals.

We also looked at the horizontal distribution pattern (if any) of the artefacts under discussion. A first step was to check if the data is normally distributed. In our analysis, we included the last two astragals to see if they show up as outliers. We did not include the piece we located by approximation, but we always checked to see how it fits within the whole. The mean and median centres produced close values (Fig. 13), which is one of the conditions for the data to be considered normally distributed.

The next step was to try to see if the features (in our case, the astragals) are dispersed or concentrated. We used standard distance for this (Fig. 14). Fourteen features $(66.66 \%)$ are located within a distance of
$0.59 \mathrm{~m}$ from the mean centre if the calculations consider one standard variation. When we consider two standard variations, $95.24 \%$ of the features (20 out of 21) are located within a standard distance of $1.18 \mathrm{~m}$ from the mean centre. Taking into account the small number of features considered, we could say they seem to be more concentrated than dispersed.

Following the above, we wanted to check if the features are not only concentrated, but also display any directional trend (Fig. 15). The calculated directional distance showed that $61.90 \%$ of features (13 out of 21 ) and $95.24 \%$ of them ( 20 out of 21 ), taking into account one and two standard deviations, display a NNE-SSW directional trend $\left(26.09^{\circ}\right.$ from North).

In both of the above cases, the two unburned astragals were within the standard distance and the directional trend, but only when two standard deviations were considered. The same applies to the astragal located by approximation.

The spatial distribution of the maximum temperatures recorded from each astragal (Fig. 16) seems to suggest that most of them might have been in the same position when the house was burnt. This supposition is based on the grouping of the astragals that were burned at a maximum $700^{\circ} \mathrm{C}$, and the fact that the others that burned at lower temperatures $\left(400-500^{\circ} \mathrm{C}\right)$ seem to cover an area to the south-west of the previous group. This would indicate that, for
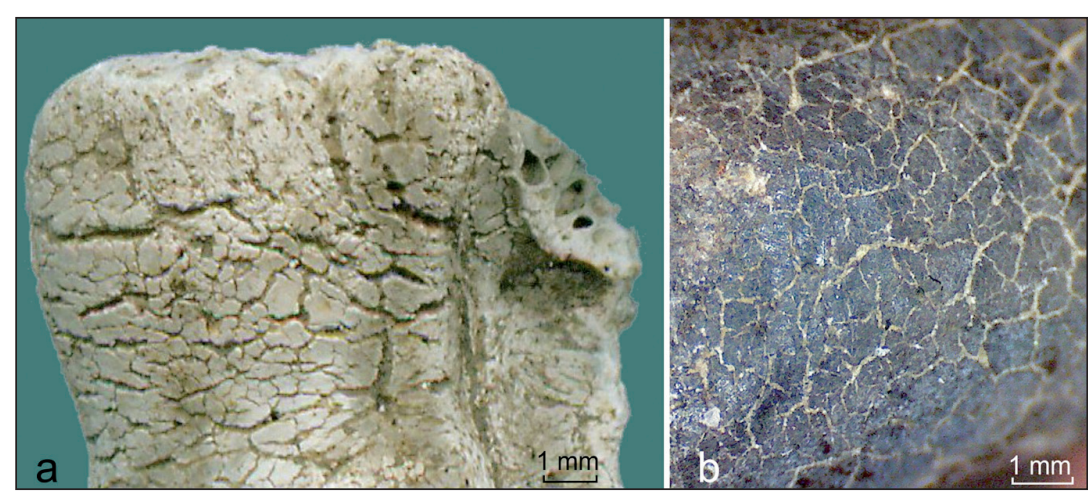

Fig. 8. Types of crack observed on the astragals. 


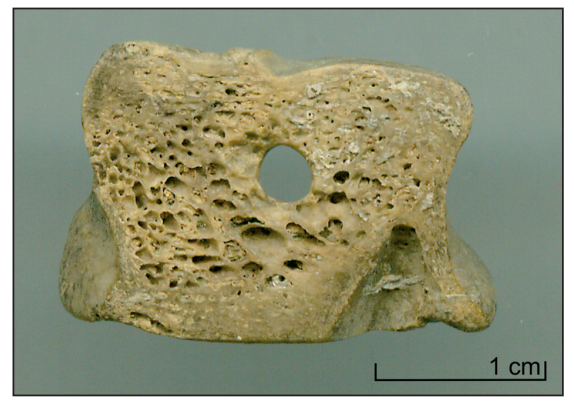

Fig. 9. Astragal with colour indicating the vicinity of heat, but not direct burning.

some reason, higher temperatures developed in a small area of less than $1 \mathrm{~m}^{2}$, while lower temperatures affected the materials around this hot spot.

An analysis of their spatial distribution and their almost uniform dimensions suggest that, in spite of their dispersal over an area of $2.5 \mathrm{~m}^{2}$, they were part of a hoard, they were kept together somewhere in the house and were dispersed when the house collapsed. As to where they might have been kept, the higher density of findings in the area of vessel no. 4 (Figs. 17 and 18) might suggest that they were contained in it. However, a few issues concerning this hypothesis should be mentioned.

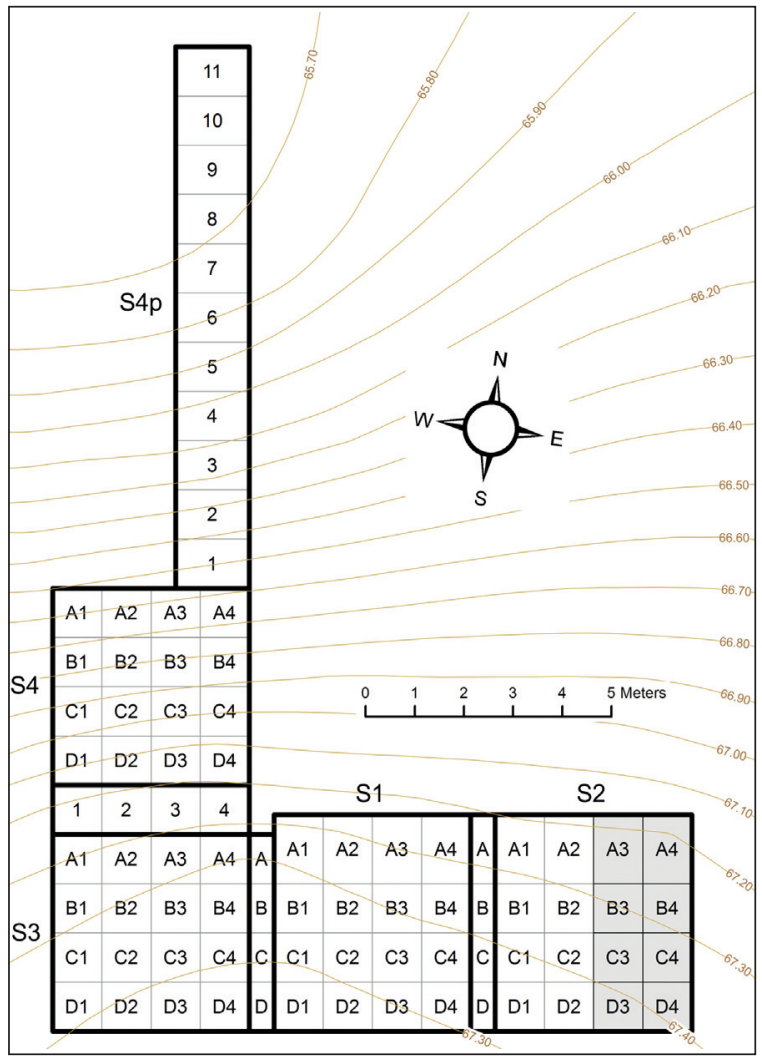

Fig. 10. Excavation plan drawn on top of the level curves - the grey squares represent the area where the astragals were found.
Firstly, if the astragals were kept inside the large vessel mentioned above $(31 \mathrm{~cm}$ high, with a rim diameter of $17 \mathrm{~cm}$ ), and the vessel fell from a height or simply fell on its side during the destruction of the house, then the astragals should have been less dispersed. On the other hand, the location of the group of astragals that was affected by higher temperatures close to the central part of vessel no. 4 might suggest a direct connection between the astragals and the vessel. Nonetheless, this connection might have resulted during or after the collapsing of the house, and not necessarily before. After all, astragals were found in the areas of the bottom or of the rim of the vessel that seem to have been less affected by fire.

We also considered the possibility that the astragals were kept in one of the other vessels from the group found in the vicinity (vessels 3 and 5) (Fig. 17). These are smaller recipients, with a larger rim diameter relative to their height, attributes which would have allowed the astragals to fall out much more easily. Nonetheless, given the location of these vessels, the direction of the astragals' distribution should have been more SE-NW, not SW-NE as recorded. But this scenario should not be entirely excluded, since variables that should be taken into account are missing, such as, for example, whether the vessel was located on the floor and flipped onto its side or was on a shelf and fell down, or if the floor was horizontal or slightly inclined, etc.

If the astragals were kept in a pouch, they should have been found either gathered in a very small area (if the pouch was on the floor or burned after reaching the floor) or very dispersed (if the pouch was burned while still hanging on the wall or on some kind of shelf).

As all the astragals had a central perforation that was supposedly used to keep them on a string, we could assume that they might have been kept in the house on a string hung from a nail in the wall. This hypothesis is supported by the impression evidence analysis of the pieces and to some degree by their dispersal pattern.

\section{Are they the result of production in situ?}

We considered the possibility that they might have been part of a workshop for making bone artefacts. According to a general schema, the presence of a workshop could be supported by the identification of all the products and sub-products that accumu- 


\begin{tabular}{|c|c|c|c|c|}
\hline $\begin{array}{l}\text { Piece } \\
\text { no. }\end{array}$ & $\begin{array}{l}\text { Burning } \\
\text { temperature }\end{array}$ & $\begin{array}{l}\text { State of bone } \\
\text { before burning }\end{array}$ & $\begin{array}{l}\text { Uniformity } \\
\text { of burning }\end{array}$ & Cracks \\
\hline 373 & $200-500^{\circ} \mathrm{C}$ & Dry & Not uniform & $\begin{array}{l}\text { Fine cracks on the surface. The cracks' pattern is random, form- } \\
\text { ing a network. }\end{array}$ \\
\hline 396 & $200-400^{\circ} \mathrm{C}$ & Dry & Not uniform & No \\
\hline 404 & $200-400^{\circ} \mathrm{C}$ & Dry & Not uniform & No \\
\hline 408 & $700-900^{\circ} \mathrm{C}$ & Green (?)* & Uniform (?) & $\begin{array}{l}\text { Network cracks on the entire surface. Some are fine, but most of } \\
\text { them are deep. }\end{array}$ \\
\hline 422 & $400-600^{\circ} \mathrm{C}$ & Dry & Not uniform & Fine cracks on the surface \\
\hline 423 & $400-700^{\circ} \mathrm{C}$ & Dry & Not uniform & No \\
\hline 424 & $500-700^{\circ} \mathrm{C}$ & Dry & Not uniform & $\begin{array}{l}\text { Fine cracks on the surface. The cracks' pattern is random, form- } \\
\text { ing a network (present mainly in the vicinity of white areas) }\end{array}$ \\
\hline 425 & $300-700^{\circ} \mathrm{C}$ & Dry & Not uniform & No \\
\hline 428 & $200-600^{\circ} \mathrm{C}$ & Dry & Not uniform & No \\
\hline 430 & $300-700^{\circ} \mathrm{C}$ & Dry & Not uniform & No \\
\hline$\overline{431}$ & $200-400^{\circ} \mathrm{C}$ & Dry & Not uniform & No \\
\hline$\overline{432}$ & $300-700^{\circ} \mathrm{C}$ & Dry & Not uniform & No \\
\hline 433 & $200-400^{\circ} \mathrm{C}$ & Dry & Not uniform & No \\
\hline 437 & $300-500^{\circ} \mathrm{C}$ & Dry & Not uniform & $\begin{array}{l}\text { A few fine cracks on the surface forming a network around the } \\
\text { perforation. }\end{array}$ \\
\hline 439 & $300-700^{\circ} \mathrm{C}$ & Dry & Not uniform & No \\
\hline$\overline{441}$ & $200-700^{\circ} \mathrm{C}$ & Dry & Not uniform & No \\
\hline 486 & $300-700^{\circ} \mathrm{C}$ & Dry & Not uniform & No \\
\hline 489 & $200-400^{\circ} \mathrm{C}$ & Dry & Not uniform & No \\
\hline 490 & $200-400^{\circ} \mathrm{C}$ & Dry & Not uniform & $\begin{array}{l}\text { A few fine cranks on the surface at one end of the piece (the part } \\
\text { having brownish-grayish coloration). }\end{array}$ \\
\hline 560 & $200-700^{\circ} \mathrm{C}$ & Dry & Not uniform & $\begin{array}{l}\text { Fine cracks on the surface. The cracks' pattern is random, form- } \\
\text { ing a network (present only in the vicinity of white areas). }\end{array}$ \\
\hline 562 & $300-500^{\circ} \mathrm{C}$ & Dry & Not uniform & No \\
\hline 638 & $300-800^{\circ} \mathrm{C}$ & Dry & Not uniform & $\begin{array}{l}\text { Fine cracks on the surface. The cracks' pattern is random, form- } \\
\text { ing a network (present only in the vicinity of white areas). }\end{array}$ \\
\hline 690 & $300-500^{\circ} \mathrm{C}$ & Dry & Not uniform & Fine surface cracks on the ridges of the proximal articulation. \\
\hline 751 & \multicolumn{4}{|c|}{$\begin{array}{l}\text { Unburned bone. The colour of the bone indicated nonetheless that it might have stayed close to a heat source, with } \\
\text { out being touched directly by the flames. }\end{array}$} \\
\hline 753 & \multicolumn{4}{|c|}{$\begin{array}{l}\text { Unburned bone. The colour of the bone indicated nonetheless that it might have stayed close to a heat source, with } \\
\text { out being touched directly by the flames. }\end{array}$} \\
\hline$* \mathrm{Tr}$ & d f & $\begin{array}{l}\text { s concerning } \\
\text { ations. }\end{array}$ & - & 5 not complete (only approximately $50 \%$ ) which prevents us from \\
\hline
\end{tabular}

\section{Tab. 3. Data concerning the burning of the astragals.}

late at the end of a technological chain, developed for the production of a certain artefact. In addition to this, the presence of a considerable number of pieces in various stages of fabrication together with the tools needed for the work would be essential characteristics of a workshop. Starting from these premises, we tried to determine if, in the case of the astragals from Iepuressti we could speak of a workshop. Unfortunately, both technological interventions identified on the astragals (abrasion and drilling) have as a result very small flakes of raw material. This makes it impossible to recover any resultant debris. In these conditions, we tried to identify tools used for drilling, such as flint drills, or flakes adapted to such activities. Their absence leads us to conclude that in this case there was no work- shop or production on the spot. This question once answered, we directed our attention to a much-debated aspect concerning the use of astragals.

\section{What were the functions of these pieces?}

The significance of these pieces has raised a lively debate in the literature due to their presence over a long span of time (from the Neolithic to modern times) and around the globe (Europe, Asia, Africa, America and Australia).

A first hypothesis concerning the function of the astragals is their domestic use. The result of intense friction against a strongly abrasive body might be an indication of its use for pottery decoration or 


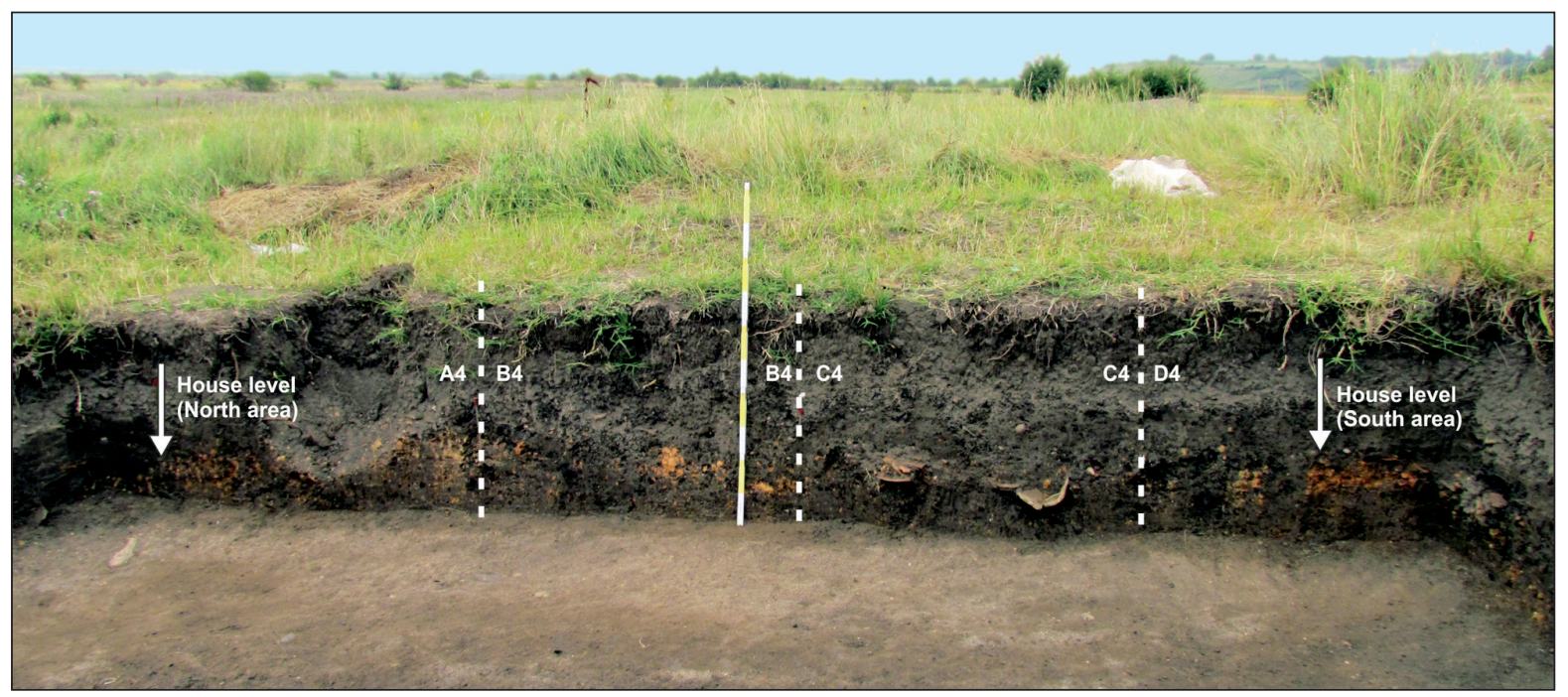

Fig. 11. Profile of the eastern wall of Section S2.

leather working (Riedel, Tecchiati 2001) which would imply that the abrasion marks are of a functional rather than a technological nature. Our own experimental studies demonstrated the great efficiency of these pieces in the process of pottery finishing while clay was still wet in order to give it a mechanical shine (present on many G-K-KVI vessels, especially small and medium sized). It was also noted that the astragal piece was completely worn down after its use on one small vessel. The same experiments showed that if the astragal was rubbed on a stone in order to obtain a flat surface, the finishing process was faster. In this last case, we can assume that the abrasion marks illustrate a stage in a technological chain whose purpose is to transform the shape of the piece in order to create a standardised final product.

Another hypothesis concerning the function of the astragals is their use in various games. Numerous such cases have been recorded around the globe and for various historical periods (pre-history, Ancient Greece and Rome, the Middle Ages, modern Iran and Mongolia, America, or among indigenous Australians) (Marckevich 1981.170-172; Lewis 1988; 1990; Elster 2003; Korzakova 2010; Choyke 2010; Amandry 1984; Gilmour 1997; Eisenberg 1989; Bartosiewicz 1999; Dandoy 1996).

In the case of some primitive populations, astragals have been used as possession markers (Perego 2010). The study of the animal bones from Iepurești showed that animal husbandry was more important than hunting, implying that the possession of domestic animals and the affirmation of this possession before the community (raising social status) might also have played an important part. The only argument against this interpretation of the astragals is the percentage of various domestic species as determined by the archaeozoological analysis: $73 \%$ cattle, $16 \%$ sheep or goat, and $11 \%$ pig1.

For cases where deposits of astragal have been found, Richard Holmgren (2004) proposed a possible commercial value, that of primitive currency. As shown by the same author, it is impossible to know if the exchange of astragals was limited to a simple gift, took place while playing various games (with no commercial value: the winner took the pieces of the other players), or was a genuine commercial exchange in the absence of a different currency.

We cannot ignore the use of astragals as amulets, as votive depositions, or in various ritual practices, such as divination (Zidarov 2005; Prummel et al. 2011. 84).

Their exceptional symbolic importance was imprinted in the collective mind. In classical antiquity, for example, astragals were copied in clay, bronze, glass or marble (Amandry 1984; Dandoy 2006). In Ancient Egypt, at Amarna, a piece showing an astragal of faience was found; two ivory astragals were identified in Tutankhamen's grave (Gilmour 1997; Dandoy 2006), and a stone astragal dating from the Bronze Age was found at Gonur Depe in Turkmenistan (Moore 1993). In the North Balkan region, a clay astragal was found at the Neolithic site at Târ-

1 The analysis of the animal bones is ongoing, so these percentages are not final, but only for orientation purposes. 
gu Frumos (Ursulescu, Boghian 1997-1998.17), and a gold one in the G-K-KVI necropolis at Varna (Poplin 1991; Slavchev 2010). Smaller than normal astragals, this last one has the same morphology as the pieces polished on the medial and dorsal faces. It also had a plantar-dorsal perforation. This piece was considered proof of an old ritual known among the Hittites, and in Ancient Greece and India, namely a ritual game part of royal ideology whereby the destiny of the king and the protection offered to him by the gods were established by the decision of the dice (Marazov 1991).

\section{The astragals from Iepurești in a wider spa- tial and temporal framework}

In the Northern Balkans, such pieces have been dated to the Middle and Late Neolithic. The earliest case known so far is two astragals from pit house 40 at Măgura/Buduiasca/TELEOR 003, attributed to the Dudeşti culture (Andreescu et al. 2006.217). Another early discovery is the ovicaprid astragals found at Cheia/Vatra satului interpreted as pottery polishers and attributed to the Hamangia culture (Voinea, Neagu 2009.97).

The polished astragals, mostly from cattle or deer, discovered in the Precucuteni II and III settlements at Ghigoeşti-Trudeşti (Marinescu-Bîlcu 1974.46-50), Isaiia (Ursulescu et al. 2004.151; Vornicu 2013.84), Târpeşti (Marinescu-Bîlcu 1974.46-50) and Târgu Frumos (Ursulescu, Boghian 1996.44; Vornicu 2013. 201-203) have also been interpreted as polishers. In some of cases, these were discovered in large numbers in the same feature, like the 20 astragals (some from sheep, most from cattle) found in Pit 2 at Târgu Frumos. The deliberate character of the deposition is suggested by the grouping of the astragals inside the pit. Along with the polished pieces, quite a large number of unpolished astragals were discovered in the same features, both at Isaiia and at Târgu Frumos (Vornicu 2013).

The analysis of the published discoveries of astragals with traces of human intervention on them found in the G-K-KVI cultural environment (especially north of the Danube) led to the identification of the following variables: context, type and degree of bone morphology modification (polishing, drilling), number of pieces/context, and the animal species from which the astragals were taken.

Such discoveries in G-K-KVI cemeteries are rare. One case is the 13 ovicaprid astragals found in Grave 4

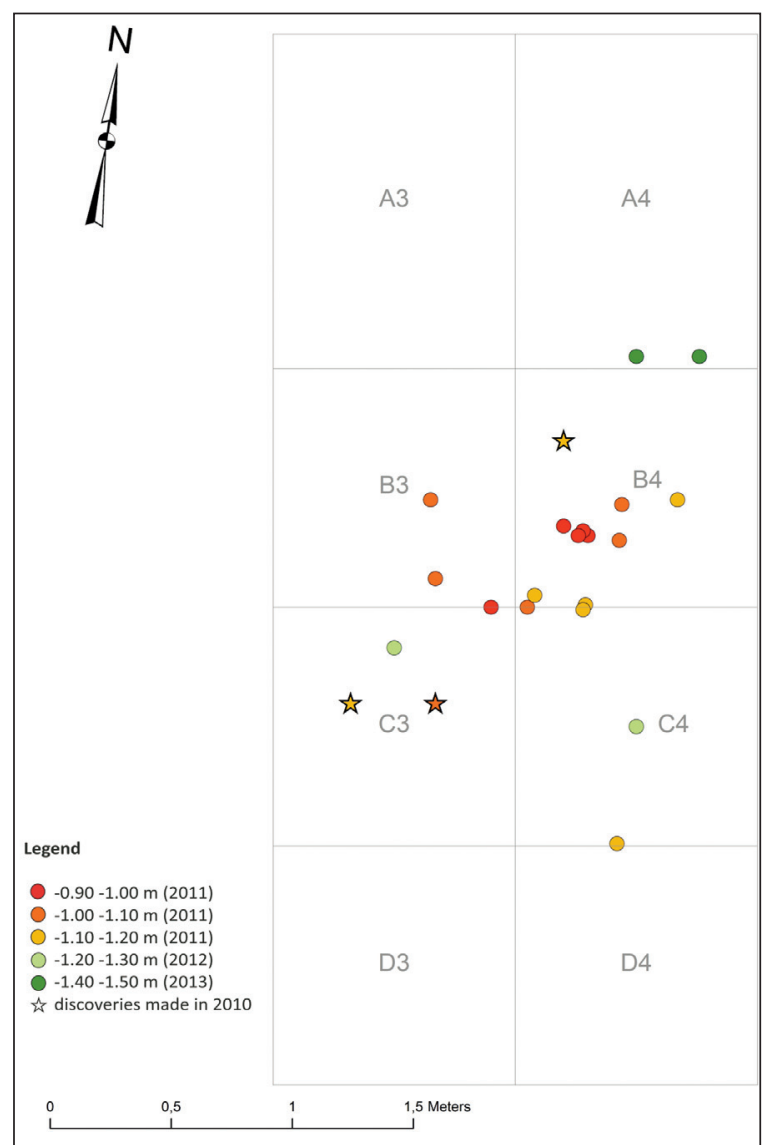

Fig. 12. Distribution of depths at which the astragals were found.

at Devnia. As five of them were polished and one perforated, they were interpreted as part of a bracelet or necklace (Todorova-Simeonova 1971.5-6). A famous discovery is the gold imitation of a perforated astragal found in Grave 36 at Varna (the richest grave in the cemetery) (Slavchev 2010.196).

In the case of the G-K-VI settlements, the analysis led to the observation of several distinct situations; unperforated astragals were involved in hearth, oven and house foundation rituals.

At Hârşova, a rectangular pit $(0.6 \times 0.35 \mathrm{~m})$ was made on the occasion of the reconstruction of a hearth $(\mathrm{C}$. 506) from House 49 from the Gumelniţa A2 level. Several astragals were deposited in the pit; unfortunately, no data on the number of pieces, animal species or interventions on the bones were published (Popovici et al. 1998-2000.18). A similar case was recorded in House 9 at Bucşani - La Pod (Gumelnița $\mathrm{B} 1$ level). Here, when the oven was being built, two polished sheep astragals together with a flint blade and a schematic clay anthropomorphic figurine were deposited in one of the construction levels (Bem 2001a.164). 


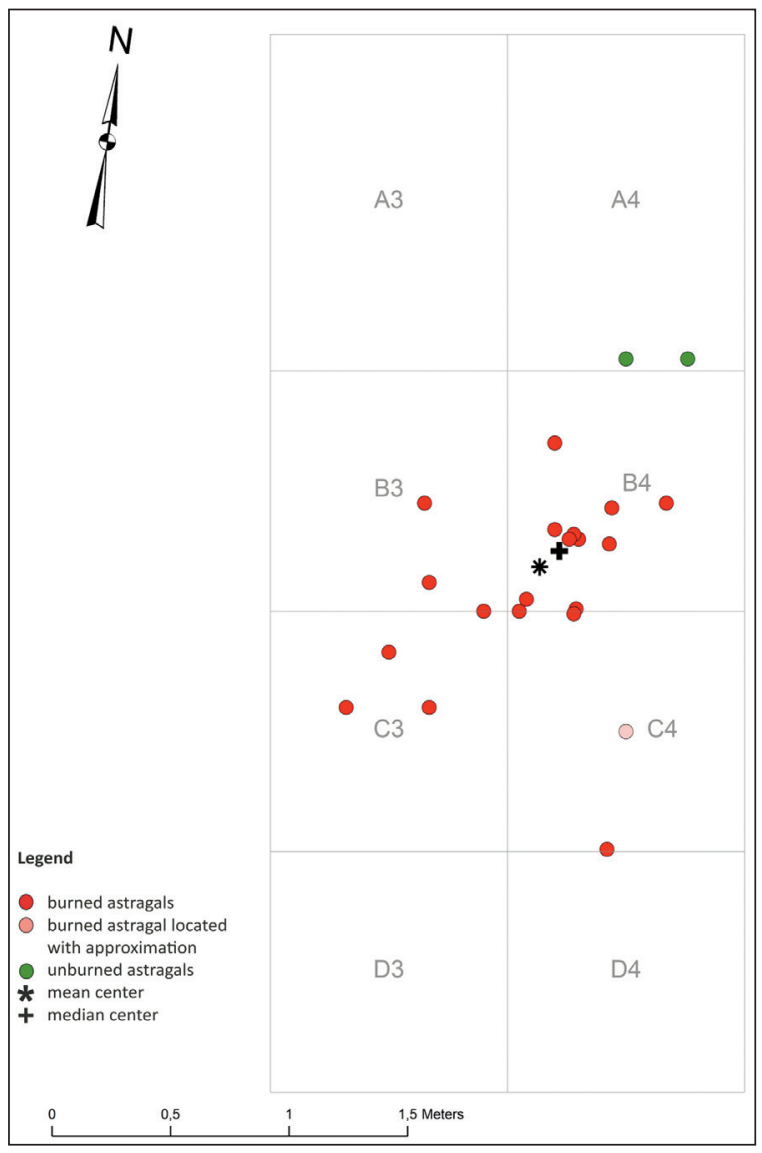

Fig. 13. Location of the mean and median centers of the astragals' distribution.

We found only one other somewhat similar situation, which is the discovery made in House 4 at Hotnitza (level III), where a house foundation ritual was recorded. The practice of depositing objects in house foundation rituals is not usually encountered in this cultural area. In the southern part of the house, laid simultaneously with the floor and plastered within it, the leg bones (phalanx, astragals, hooves) of 23 animals (16 cows, two ovicaprids, three pigs, one deer and one auroch) were found; 32 of these were astragals (Chokhadzhiev, Chokhadzhiev 2005.11; Chokhadziev 2009.68, Fig. 13). We do not have data on any human intervention on the bones.

The same interpretation (i.e. house foundation ritual) could also be proposed for the situation at $\mathrm{Gu}-$ melniţa, where a deposit of small sheep astragals (from young individuals?) polished on one side was discovered at the base of the upper level (Gumelnița B1) (Dumitrescu 1966.59).

Discoveries of astragals inside buildings are more numerous. Thus, in a burned building of level III at
Pietrele (Gumelniţa A2), interpreted, based on the exceptional inventory, as a sanctuary, 13 astragals were deposited to the left of the entrance, together with a prismatic idol and two herbivore hooves. At least one of the astragals was decorated with incised lines (Berciu 1956.512). No data were published concerning the animal species from which the astragals were taken, or whether they had been modified in any way, such as by drilling or polishing. It was only mentioned that they had been "worked on carefully".

Other discoveries of pig and cattle astragals deposited together were made in the burned Houses 2 and 4 at Căscioarele (Gumelniţa B1 level). Some had been polished, but no other data were published (Dumitrescu 1965.225). The first house was interpreted as a flint axe workshop (Marinescu-Bîlcu 1965), while the second was called the "fisherman's house" (Marinescu-Bîlcu 2002). In both cases, the inventory was rich, diverse, and included exceptional elements (due to the character of the artefacts, or their number: moulds for casting axes, 100 clay weights, 13 flint axes, etc.).

Another polished and perforated piece was found at Drăgăneşti-Olt in the filling of pit house 2, in association with pottery, partially burned deer bones, a miniature mask representing a horse head and other several clay artefacts (Nica et al. 1977.10, Fig. $3 / 3 a-b$ ). Four polished ovicaprid astragals, one perforated, were found in a vessel in House 5, and one polished cattle astragal was found in House 6 at Mălăieştii de Jos/La Mornel. Both houses had been destroyed by fire (Frinculeasa et al. 2011). Two or four $^{2}$ ovicaprid astragals, of which at least two were abraded and one perforated, were found at Măriuţa/ La Movilă (Gumelniţa B1), in a deposit including numerous bone and antler tools, grinding stones, axes, etc. (Parnic, Păun 2003-2004.57-58; Mărgărit et al. in press). Three polished (?) astragals were found in a house at Năvodari/Insula La Ostrov (Marinescu-Bîlcu et al. 2003.210). We presume that the deposit of seven polished astragals discovered at Hârşova (of which six were ovicaprid) (Haşotti 1997. 105), as well as a deposit consisting of 20 perforated ovicaprid (young individuals) astragals, of which three were decorated with incisions and at least two with ochre, and interpreted as necklaces (Popovici, Rialland 1996.54-55) were also found inside houses.

2 The number varies according to the source used. 
Astragals showing traces of abrasion, and sometimes perforation, were recorded (separately or in groups of two or three) in other contexts such as in middens, foundation trenches, etc. at Urlați (two perforated and polished pig astragals in a midden pit; Frînculeasa et al. 2008.97), Chitila/Fermă (Nicolae et al. 2003.78-80), Măriuța/La Movilă (three abraded astragals in a refuse area; Mărgărit et al. in press), Cuneşti/Măgura Cuneştilor (Mărgărit et al. 2013), Însurăței/Popina I (six polished astragals in a refuse area located between two houses; Pandrea 2002.172), Borduşani (10 polished ovicaprid astragals, one of which is perforated, found in foundation trenches and in the archaeological strata; Voinea 1997. 75), Năvodari (two polished astragals found in a pottery complex; Marinescu-Bîlcu et al. 2000.66; Marinescu-Bîlcu et al. 2001.160), and others.

This enumeration of known situations suggests that the perforated pieces appear quite rarely. We do not know if this image is real or it is due to a shortcoming in the publication of materials. With the exception of the cases already mentioned (Mălăieşti, Urlați, Chitila, Drăgăneşti and Hârşova), there are no data on other discoveries of perforated astragals. The lot discovered at Iepurești can be now added to this list. In all these cases, although the number of pieces is different, the common element is the provenance of the bones from (young) ovicaprid individuals (with the exception of the piece from cattle found at Chitila). The same can be said for the discovery made at Devnia.

It should also be noted that during the Copper Age, in the cultural areas neighbouring the G-K-KVI cultural complex, such pieces are quite rare, perforated or otherwise. Two astragals were discovered in the IIb and IIc layers at Priscul Cornişorului (Sălcuţa culture) (Вегсіи 1961.233).

A recent revaluation of the bone and antler artefacts from sites located in the area of contact between the Gumelniţa and Cucuteni cultures (Stoicani-Aldeni aspect) (Beldiman et al. 2012) did not lead to the identification of any modified astragals. The picture of this area may be false, due to the small number of recent archaeological investigations.

The discoveries of cattle and ovicaprid astragals in the numerous Cucuteni A settlements investigated are rare, and usually refer to a small number of pieces. The usual interpretation of such finds is that of polishers. Two ovicaprid astragals with traces of polishing were discovered at Hoiseşti/La Pod (Bodi

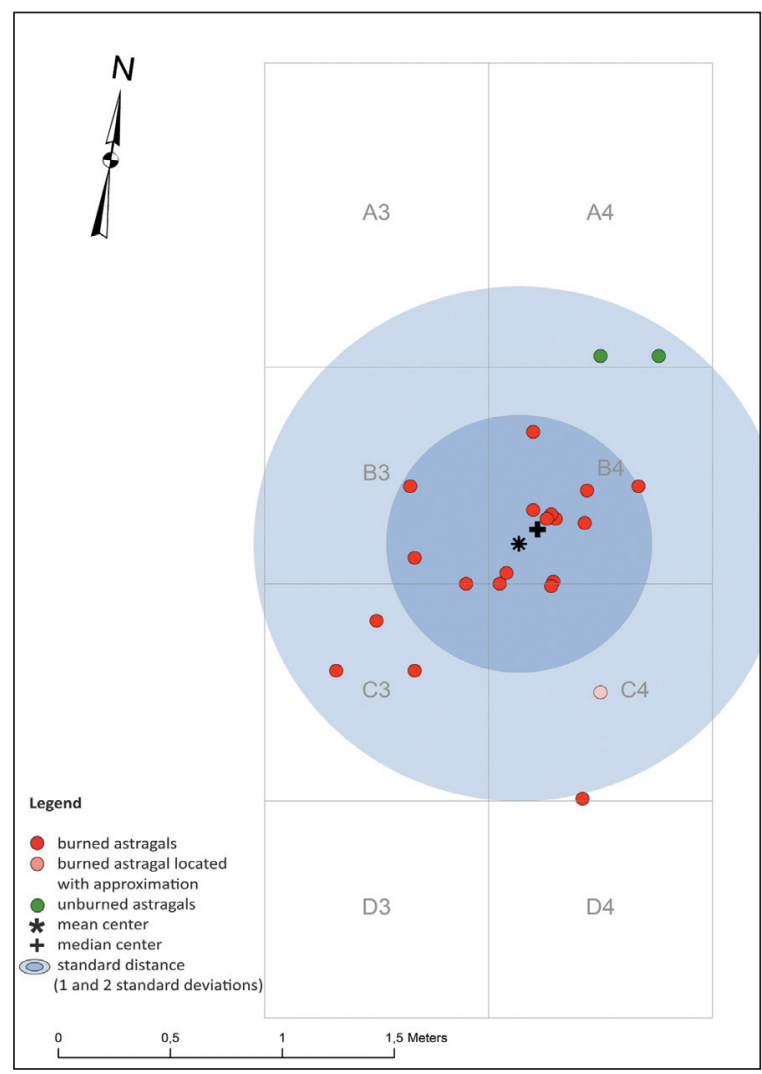

Fig. 14. The calculation of the standard distribution to determine the degree of concentration of finds.

2010.117, 120-121). In all, this site yielded 23 astragals from various species, both wild (Capreolus capreolus - 5, Sus scrofa ferus - 9, Bos primigenius - 2) and domestic (Bos Taurus - 1, Sus scrofa domesticus - 1, Ovis aries - 2, Ovis/Capra - 3) (Cavaleriu, Bejenaru 2010.224). Eight polished cattle astragals were discovered at Poduri/Dealul Ghindaru, in a refuse area (Bejenaru et al. 2010). Several more or less polished cattle astragals, some burned, were discovered at Tîrpești (Marinescu-Bîlcu 1981). A polished astragal from a domesticated ox was found at Drăguşeni/Ostrov (Bolomey, Marinescu-Bîlcu 2000.75). Several astragals, some polished, were discovered at Dumeşti/Între Pâraie, in House 3 (pottery workshop) on the floor of the larger room (Alaiba 2007.20-23). Five ovicaprid astragals, of which one is perforated, were discovered in a vessel at Bonţeşti (Dumitrescu 1933.97).

Although many sites have been investigated and published in the past (Hăbăşeşti - Dumitrescu et al. 1954; Izvoare - Vulpe 1957), or others more recently excavated that benefited from archaeozoological studies (Preuteşti/Haltă - Ursulescu, Ignătescu 2003; Truşeşti/Ţuguieta - Petrescu- Dîmbovita et al. 1999; Ruginoasa/Dealul Drăghici - Lazarovici, Lazarovi- 


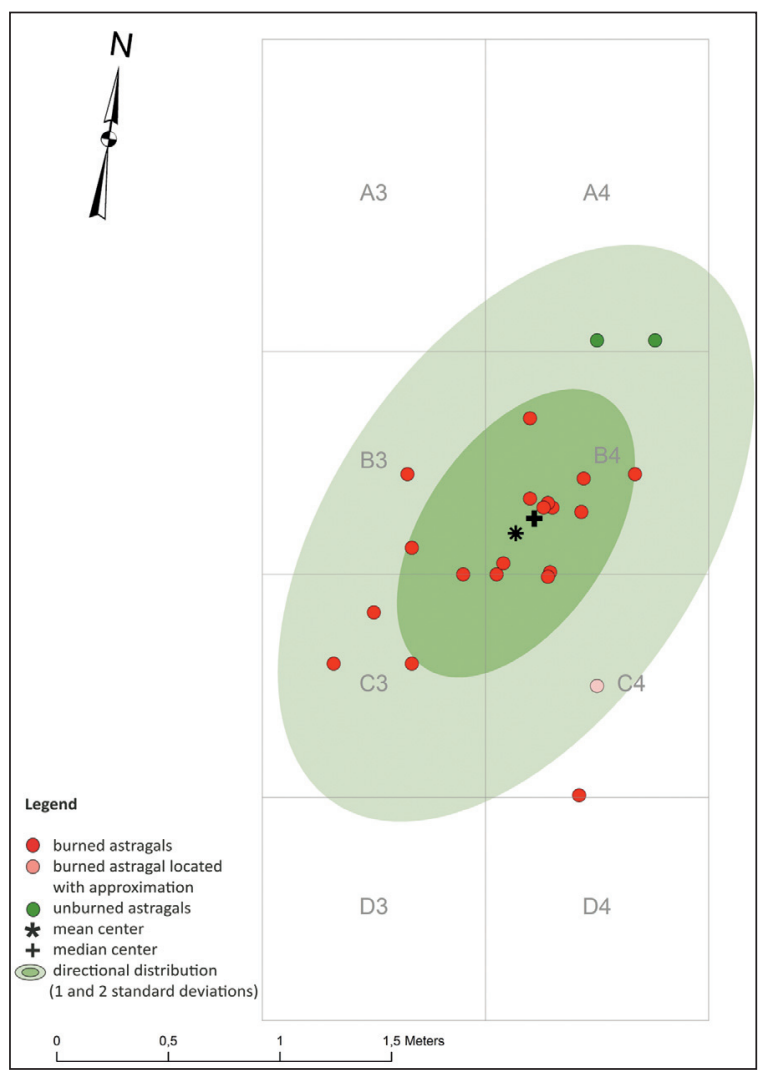

Fig. 15. The calculation of the directional distance in order to observe any trend in the dispersal of finds.

ci 2012; Cucuteni/Cetătuie - Petrescu-Dîmbovita, Văleanu 2004), the presence of astragals is very rarely recorded, and the pieces do not bear traces of abrasion, polishing, drilling or decoration.

Several notable exceptions, both from Cucuteni A settlements, should be mentioned. One was encountered at Poduri/Dealul Ghindaru, where 25 astragals of mature individuals (21 cattle, three deer, one ovicaprid) were discovered beneath the floor of a house. Some of the pieces have processing traces and were pigmented with ochre. A green colouration from contact with copper was noted on some of them. The discovery was interpreted as the final destination of dice-type artefacts deposited in the foundation of the house to bring good luck to the building (Bejenaru et al. 2010). Although the ritual practice of placing objects in the foundations of buildings or combustion structures is frequent, the use of astragals for this purpose is unusual. On the other hand, related to the discovery at Poduri, we must note that the main meat component in the food in that site was from cattle (which also constitute the main component of the foundation deposit).
Another rare discovery was recorded at the site at Şoimeni-Ciomortan/ Dâmbul Cetătiii3: a perforated ovicaprid astragal and another one decorated with incisions were discovered in two different features (Kavruk et al. 2010.185; 2013.128; Beldiman, Sztancs 2010.143, 153).

So far, these two contexts appear to be unique to the Cucuteni culture. They could be explained by the special position that the two sites occupied in the network of social and economic relations. In the case of the first site, the richness and multitude of discoveries associated with rituals led the archaeologists to consider it a 'Troy' of Cucuteni culture (Monah et al. 2003). In the case of the second site, there was the possibility of controlling access routes between the areas east of the Carpathians and those inside the mountain arch, which included the possibility of controlling the distribution of salt extracted in Moldavia (Cavruc 2005.333-336).

The Cucuteni A-B phase is represented by only two discoveries (probably due to the limited number of

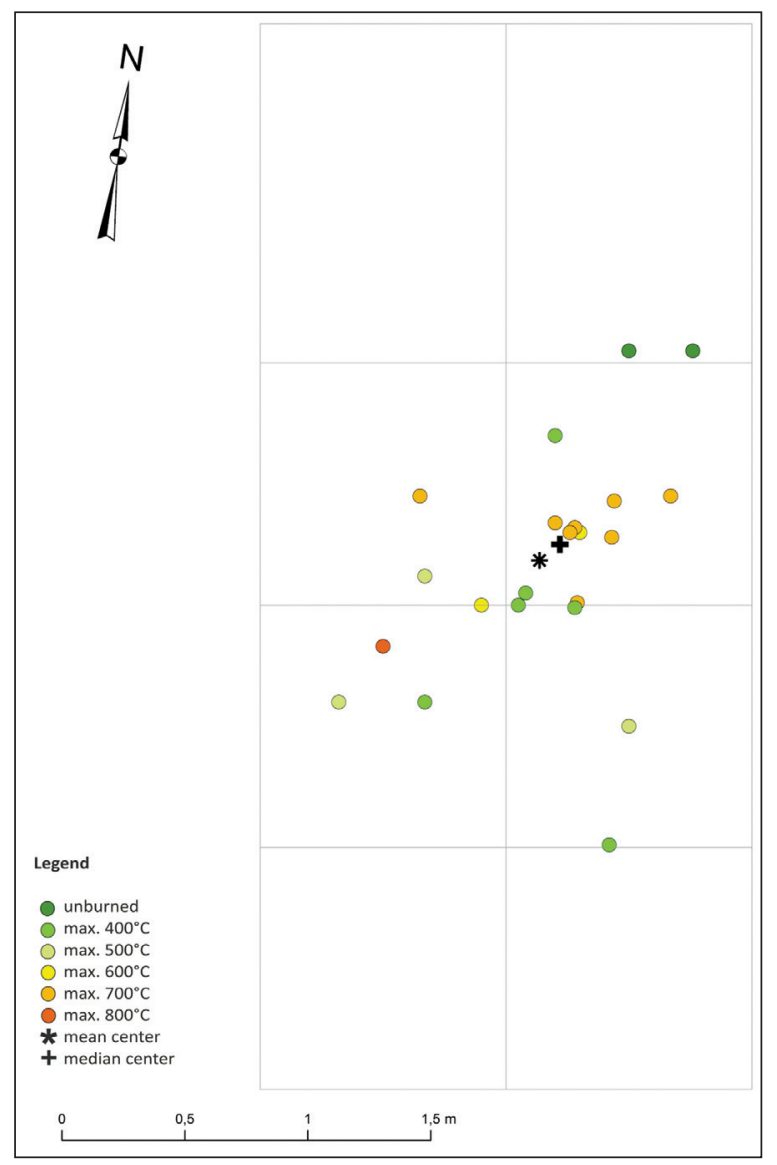

Fig. 16. Spatial distribution of the highest temperatures of burning recorded from the astragals.

3 The site is also known in literature under the name of Păuleni-Ciuc/Dâmbul Morii. 
investigated contexts): five polished ovicaprid astragals were found at Traian/ Dealul Fântânii (Bem 2007.179), and two deposits of 22 small astragals, one of them found in a globular vessel covered with a river stone, were discovered at Huşi/Centrul oraşului (Niţu, Bazarciuc 1980.19).

Several other discoveries have been recorded for the last phase of the Cucuteni culture (phase B). A polished pig astragal and a sheep astragal were discovered at Fetești/La Schit (Oleniuc 2012.61, 62). Another astragal was discovered under a small vessel in the shape of a truncated cone, turned upside down, in House 7 at Roma/Balta lui Ciobanu (Popovici et al. 1992.16) no data is available on the species or on processing. Sixteen perforated (?) ovicaprid astragals were found in a vessel at Brânzeni III in association with a flint knife and a piercing tool. They were interpreted as pieces of a game that also involved small clay cones (Marckevich 1981.171). A spectacular discovery is that of a deposit consisting of 497 astragals ( 489 from ovicaprid individuals and 8 from pig, one of which was polished) found at Ghelăiesti. Some of the ovicaprid astragals showed several types of human intervention on them: traces of the butchering process and of the rubbing of the astragal against another object, incisions (on some of them), and perforations (on two pieces). The minimum number of individuals that these astragals came from is 253 ovicaprids and 7 pigs. The group of astragals is characterised by a wide variation in the dimensions of the individual astragals (Necrasov 1999.192). The deposit was found in House 5 in a large storage vessel with a curved shoulder and crater neck (Cucos 1999.4849). Another astragal, with one of the sides strongly abraded and with the upper margins slightly denticulated was found in house 23 of the same site (Cucos 1999.69). Some of the astragals might have been used as amulets or simple adornments, the rest of them were most probably used as stone tools and pottery polishers (Cucoş 1999.69).

The simple enumeration of contexts can illustrate, but does not assure, the identification of the ways this category of artefacts was employed. We do not exclude the possibility that, according to context, the function might have changed, or that the pieces might have received multiple cultural/symbolic values. The cultural values associated with these artefacts can also vary from one culture to another, as appears obvious from the comparison between the discoveries made in the Cucuteni area and those made in the G-K-KVI area. In the Cucuteni A environment, there is a pre-Cucuteni tradition of using preponderantly cattle astragals which are hardly processed or not at all. In spite of a tradition (Dudești and Hamangia) in which the astragals seem to have been employed in a manner similar to the later Cucuteni one, an individualisation takes place in the G-K-KVI environment, a transformation of this artefact that underwent a rich symbolic investment. This transformation is very well illustrated by the variety of contexts in which they were discovered and by the preferred animal species (ovicaprid). 


\section{Conclusions}

In traditional societies, the sacred and the profane are perceived as being intertwined, and practical, daily activities have a mythical connotation. In these societies, objects are invested with symbols that, according to the moment or area, can be simplified, amplified or modified. Several classes of artefacts can be identified for the G$\mathrm{K}$-KVI cultural complex. The most visible category is that of prestige goods, including copper axes, certain shapes of stone or bone ax,

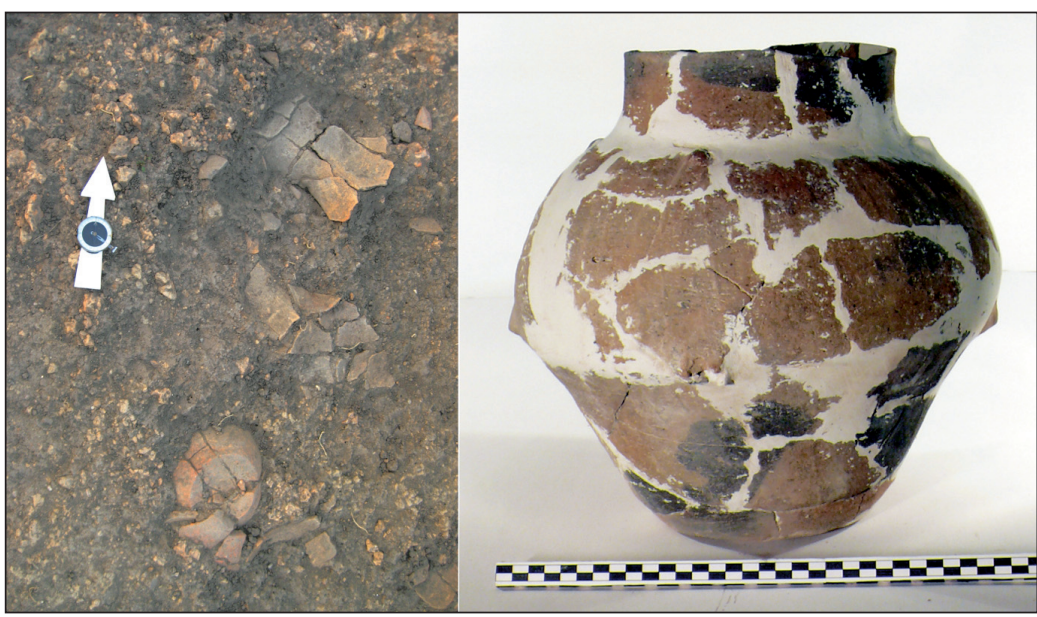

Fig. 18. Vessel no. 4 in situ and reconstructed. gold and Spondylus artefacts, etc. They are usually encountered over large areas and are appropriate for long-distance trade. A second category would be that of identity goods, such as adornments and anthropomorphic figurines. Another group is comprised of symbolic goods, such as objects used in foundation rituals (pottery, flint and stone tools, adornments, figurines, astragals, etc.).

Astragals form a category of artefacts that can be easily obtained through the selection of these bones when animals are sacrificed. Nonetheless, their availability is limited by the existence of only two such bones per animal. Obtaining and processing them does not imply important efforts; even an untrained person can perform these actions in any household. Our own experiments (and another traseological analysis (Meier 2013)) which focused on the use of astragals for polishing vessels and processing leather would indicate that these artefacts were not used as tools in such activities.

The specific archaeological contexts of discovery for the G-K-KVI cultural complex suggest that the astragals, mostly ovicaprid, in some cases had a symbolic importance, being used in foundation rituals for houses or combustion structures. They were deposited in graves very rarely, although this aspect changed in the ensuing periods when astragals were used preponderantly in funerary contexts, public areas and, more rarely, private spaces (Minniti, Peyronel 2005; Carè 2013). Nonetheless, the smaller or larger number of pieces per context, and the association of pieces with different degrees of processing or from dif- ferent species suggest their use for various purposes/ practices.

From an economic perspective, recent studies (Bréhard, Bălăsescu 2012) suggest, in spite of the decreasing importance of small horned animals in Gumelniţa culture, the development a specialised form of exploiting ovicaprids, especially of sheep, for meat. While cattle were usually associated with masculinity, as suggested by a series of gold or clay representations (vessels with horned protomes, masks, bucrania), the ovicaprids might have been connected with older traditions in which they played important social and economic roles. With time, in virtue of this importance, certain parts of the animal became sacred, employed in house protection rituals, or perhaps even for personal protection in the case of perforated pieces. The archaeological situations suggest that these objects might have been invested with symbolism whether they were processed or not.

In these conditions and having in mind the scarcity of archaeological information available, the attention paid to these artefacts when they are found could yield new clues about how they were used in a social setting. The discovery made at Iepurești is part of a universal tradition of using perforated and abraded astragals as old as the Neolithic. A common local animal species (that probably played an important economic role) was used for all the studied pieces. Standard blanks that made a strong visual impact were selected, especially if we presume they formed parts of a necklace. 
Monica Mărgărit's work on this material was supported by a grant of the Romanian National Authority for Scientific Research, CNCS-UEFISCDI, project number PN-II-RU-TE-2011-3-0133. We also wish to thank for their support with the bibliography and additional data, colleagues Alin Frinculeasa (additional data on the discoveries made at Mă lă iești and Urlaţi), Pavel Mirea (additional data on discoveries made at Mă gura/Buduiasca/TELEOR 003), and Andreea Vornicu (additional data on discoveries made at Isaiia and Târgu Frumos), Bogdan Niculică and Sorin Ignătescu.

\section{$\therefore$}

\section{References}

Alaiba R. 2007. Complexul cultural Cucuteni-Tripolie. Meșteşugul olăritului. Junimea. Iași.

Amandry P. 1984. Os et coquilles. In L'Antre corycien II, Bulletin de Correspondance Hellénique. Supplément 9. École Française d'Athènes. Athènes. Paris: 347-380.

Andreescu R., Mirea P. 2008. Tell Settlements: a pattern of landscape occupation in the Lower Danube. In D. W. Bailey, A. Whittle, D. Hofmann (eds.), Living Well Together? Settlement and Materiality in the Neolithic of South-East and Central Europe. Oxbow Books. Southampton: $28-34$.

Andreescu R. R., Bălăşescu A., Haită C., Moldoveanu K., Radu V., Lazăr C., Mirea P., Zaharia P., Feleagă R., Crăciun I., Bailey D. W., Mills S., Jones G. and Reeves J. 2006. Măgura, com. Măgura, jud. Teleorman. Punct: Buduiasca, TELEOR 003. In Cronica Cercetărilor Arheologice din România. Campania 2005. cIMeC - Institutul de Memorie Culturală. Bucureşti: 216-218.

Bartosiewicz L. 1999. A systematic review of astragalus finds from archaeological sites. In A. Vaday (ed.), Pannonia and Beyond. Studies in Honour of László Barkóczi. Antaeus. Communicationes ex Instituto Archaeologico Academiae Scientiarum Hungaricae 24. Budapest: 37-44.

Bejenaru L., Monah D. and Bodi G. 2010. A deposit of astragali at the Copper Age tell of Poduri - Dealul Ghindaru, Romania. http://www.antiquity.ac.uk/projgall/bejena ru323/.

Beldiman C., Sztancs D. M. 2010. Date asupra industriei materiilor dure animale aparţinând culturii Cucuteni-Ariuşd descoperită în aşezarea de la Păuleni-Ciuc - "Dâmbul Cetătii”, jud. Harghita. Angustia 14: 141-164.

Beldiman C., Sztansc D. M. and Ilie C. 2012. Artefacte din materii dure animale in colectria Muzeului de Istorie Galati. Eneolitic. Catalog. Mega. Timişoara.
Bem C. 2001a. A special Type of Aeneolithic Dwelling. Unicum or Deficiency of Conservation? Studii de Preistorie 1: 153-192.

2001b. Noi propuneri pentru o schiţă cronologică a eneoliticului românesc. Pontica 33-34: 25-122.

2007. Traian Dealul Fântânilor. Fenomenul Cucute$n i A-B$. Muzeul National de Istorie a României Monografii V. Cetatea de Scaun. Bucureşti-Târgovişte.

Bem C., Popa T., Parnic V., Bem C., Garvăn D., Bărbulescu D. and Găluşcă I. 2001. Cercetări arheologice pe Valea Neajlovului. Consideraţii generale asupra microzonei $\mathrm{Bu}$ cşani. Studii de Preistorie 1: 131-146.

Berciu D. 1956. Cercetări şi descoperiri în regiunea $\mathrm{Bu}$ curești. Materiale şi Cercetări Arheologice II: 493-562.

1961. Contribuţii la problemele neoliticului în România în lumina noilor cercetări. Romanian Academy Publishing House. Bucureşti.

Bodi G. 2010. Hoisești - La Pod. O așezare cucuteniană pe valea Bahluiului. Institutul de Arheologie Iaşi. Bibliotheca Archaeologica Moldaviae XII. Pim Publishing House. Iaşi.

Bolomey A., Marinescu-Bîlcu S. 2000. The bone and antler industry. In S. Marinescu-Bîlcu, A. Bolomey (eds.), Drăguşeni. A Cucutenian Community. Editura Enciclopedică. Bucureşti: 63-89.

Bréhard S., Bălăsescu A. 2012. What's behind the tell phenomen? An archaeozoological approach of Eneolithic sites in Romania. Journal of Archaeological Science 39(10): 3167-3183.

Carè B. 2013. Knucklebones from the Greek Necropolis of Locri Epizefiri, Southern Italy (VIth-IIIth century BC). Typological and functional analysis. In F. Lang (ed.), The 
Sound of Bones. Proceedings of the $8^{\text {th }}$ Meeting of ICAZ Worked Bone Research Group in Salzburg, 2011. Felix Lang. Salzburg: 87-100.

Cavaleriu R., Bejenaru L. 2010. Analiza materialului arheozoologic. In G. Bodi (ed.), Hoiseşti - La Pod. O aşezare cucuteniană pe valea Bahluiului. Bibliotheca Archaeologica Moldaviae XII. Pim. Iaşi: 219-224.

Cavruc V. 2005. Some Eneolithic and Bronze Age funeral evidence on the salt exchange routs in Southeast Transylvania. Mousaios X: 325-351.

Chokhadziev A. 2009. The Hotnitsa tell - 50 years later. Eight years of new excavations - some results and perspectives. In F. Draşovean, D. L. Ciobotaru and M. Maddison (eds.), Ten years after: the Neolithic of the Balkans, as uncovered by the last decade of research. Bibliotheca Historica et Archaeologica Banatica XLIX. Marineasa Publishing House. Timişoara: 67-84.

Chokhadzhiev S., Chokhadzhiev A. 2005. Some results of the investigations of Hotnitsa tell in 2001. In L. Nikolova, J. Fritz and J. Higgins (eds.), Prehistoric Archaeology $\&$ Anthropological Theory and Education. Reports of Prehistoric Research Projects 6-7. Salt Lake City: 9-12.

Choyke A. 2010. The Bone is the Beast: Animal Amulets and Ornaments in Power and Magic. In D. Campana, P. Crabtree, S. D. Defrance, J. Lev-Tov and A. Choyke (eds.), Anthropological Aproaches to Zooarchaeology. Complexity, Colonialism, and Animal Transformations. Oxbow Books. Oxford and 0akville: 197-209.

Cucoş Ş. 1999. Faza Cucuteni B în zona subcarpatică a Moldovei. Bibliotheca Memoriae Antiquitatis VI. C. Matasă Publishing House. Piatra-Neamţ.

Dandoy J. 1996. Astragali, the Ubiquitous Gaming Pieces. Expedition 38(1): 51-58.

2006. Astragali through Time. In M. Maltby (ed.), Integrating Zooarchaeology. 9th ICAZ Conference, Durham 2002. Oxbow Books. Oxford: 131-137.

Dumitrescu V. 1933. La station préhistorique de Bonţești. Dacia III-IV: 88-114.

1965. Principalele rezultate ale primelor două campanii de săpături din aşezarea neolitică târzie de la Căscioarele. Studii și Cercetări de Istorie Veche 16(2): 215-237.

1966. Gumelniţa. Sondajul stratigrafic din 1960. Studii şi Cercetări de Istorie Veche 17(1): 51-100.
Dumitrescu V., Dumitrescu H., Petrescu-Dîmboviţa M. and Gostar N. 1954. Hăbăsești. Monografie arheologică. Romanian Academy Publishing House. Bucureşti.

Eisenberg L. E. 1989. On Gaming Pieces and Culture Contact. Current Anthropology 30(3): 345.

Elster E. S. 2003. Bone Tools and Other Artifacts. In E. L. Elster and C. Renfrew (eds.), Prehistoric Sitagroi: Excavations in Northeast Greece, 1968-1970, vol. 2 - The Final Report. Monumenta Archaeologica 20. Cotsen Institute of Archaeology at UCLA. Los Angeles: 31-79.

Frînculeasa A., Niţă L. and Dumitraşcu V. 2008. Descoperiri aparţinând culturii Gumelniţa de la Urlaţi (jud. Prahova). Acta Musei Tutovensis III: 94-111.

Frînculeasa A., Andreescu R., Negrea 0., Niţă L., Frînculeasa M., Popa E. and Preda B. 2011. Cercetări arheologice în aşezarea eneolitică de la Mălăieștii de Jos (jud. Prahova), campaniile 2002-2010. Materiale şi Cercetări Arheologice (S.N.) VIII: 11-58.

Gilmour G. H. 1997. The Nature and Function of Astragalus Bones from Archaeological Contexts in the Levant and Eastern Mediterranean. Oxford Journal of Archaeology 16(2): 167-175.

Haită C. 2001a. Preliminary consideration on a sedimentary sondage performed on the Eneolithic tell from Bucşani. Studii de Preistorie 1: 147-152.

2001b. Studiul sedimentologic preliminar asupra locuirii neo-eneolitice din Valea Teleormanului, zona LăceniMăgura (Southern Romanian Archaeological Project). Studii de Preistorie 1: 47-58.

Haşotti P. 1997. Epoca neolitică în Dobrogea. Muzeul de Istorie Natională şi Arheologie. Bibliotheca Tomitana I. Constanţa.

Holmgren R. 2004. "Money on the hoof" The astragalus bone - religion, gaming and primitive money. In B. S. Frizell (ed.), PECUS. Man and animal in antiquity. Proceedings of the conference at the Swedish Institute in Rome, September 9-12, 2002. Projects and Seminars 1. The Swedish Institute in Rome. Rome: 212-220.

Ilie A. 2011. Tell settlements on the upper course of Neajlov River. In R. Kogălniceanu and S. Morintz (eds), Tells a the Lower Danube. Muzeul Judeţean Giurgiu. Archaeological Debates 1. Pelican Publishing House. Giurgiu: 33-70.

Kavruk V., Buzea D. L., Mateş A., Lazarovici G., Dumitroaia G., Garvăn D., Munteanu E. R., Sztancs D.-M. and Beldiman C. 2010. Şoimeni - Ciomortan, com. Păuleni Ciuc, jud. Harghita, Punct: Dâmbul Cetăţii. In Cronica Cercetă- 
rilor arheologice din România. Campania 2009. cIMeC - Institutul de Memorie Culturală. Bucureşti: 180-186.

Kavruk V., Buzea D. L., Mateş A., Lazarovici G., Munteanu E. R., Garvăn D., Beldiman C. and Sztancs D.-M. 2013. Şoimeni (Ciomortan), com. Păuleni-Ciuc, jud. Harghita, Punct: Dâmbul Cetăţii. In Cronica Cercetărilor arheologice din România. Campania 2012. cIMeC - Institutul de Memorie Culturală. Bucureşti: 124-128.

Kogălniceanu R., Haită C. and Morintz A. S. 2012. Investigations outside the settlement of Iepureşti (Giurgiu County). In A. S. Morintz, R. Kogălniceanu (eds.), Survey in Archaeology, often a neglected science. Muzeul Judetean Giurgiu. Archaeological Debates 2. Pelican Publishing House. Giurgiu: 199-216.

Korzakova H. B. 2010. Astragali. In A. Kloner, E. Esher, H. B. Korzakova and G. Finkielsztejn, Maresha Excavations. Final Report III. Israel Antiquities Authority. IAA Reports no. 45. Israel: 155-156.

Lazarovici C. M., Lazarovici G. 2012. Ruginoasa - Dealul Drăghici. Monografie arheologică. Institutul de Arheologie Iaşi. Bibliotheca Archeologica Moldaviae XX. Karl A. Romstorfer Publishing House. Suceava.

Lewis R. B. 1988. Old World Dice in the Protohistoric Southern United States. Current Anthropology 29(5): 759-768.

1990. On Astragalus Dice and Culture Contact: Reply to Eisenberg. Current Anthropology 31(4): 410-413.

Marazov I. 1991. Grave No. 36 from the Chalcolithic Cemetery in Varna: Myth, Ritual and Objects. In J. Lichardus (ed.), Die Kupferzeit als historische Epoche. Symposium Saarbrucken und Otzenhausen 6.-13.11.1988. Teil 1. Dr. Rudolf Habelt GMBH. Bonn: 151-155.

Marckevich V. I. 1981. Late-Tripolian Tribes of Northern Moldavia. Ştiinţa. Kishinev.

Marinescu-Bîlcu S. 1965. Un "atelier" néolithique pour la taille de haches en silex. Archeologické Rozhledy XVII: 48-53.

1974. Cultura Precucuteni pe teritoriul României. Romanian academz Publishing House. Bucureşti.

1981. Tîrpesti. From Prehistory to History in Eastern Romania. British Archaeological Reports IS 107. Archaeopress. Oxford.

2002. A few observations on the internal organization of Gumelniţa communities on Lake Cătălui Islet. Cultură şi Civilizatie la Dunărea de Jos XIX: 147-153.
Marinescu-Bîlcu S., Voinea V. and Dumitrescu S. 2000. Nă vodari, jud. Constanţa. Punct: Insula La Ostrov, Lacul Taşaul. In Cronica Cercetărilor Arheologice din România. Campania din 1999. cIMeC - Institutul de Memorie Culturală. Bucureşti: 65-67.

Marinescu-Bîlcu S., Voinea V., Dumitrescu S., Radu V., Haită C. and Moise D. 2001. Năvodari, jud. Constanţa. Punct: Insula La Ostrov, Lacul Taşaul. In Cronica Cercetărilor Arheologice din România. Campania din 2000. cIMeC Institutul de Memorie Culturală. București: 159-163.

Marinescu-Bîlcu S., Voinea V., Dumitrescu S., Radu V. and Pătroi C. 2003. Năvodari, jud. Constanţa. Punct: Insula La Ostrov, Lacul Taşaul. In Cronica Cercetărilor Arheologice din România. Campania 2002. cIMeC - Institutul de Memorie Culturală. Bucureşti: 210-212.

Markussen C., Vornicu M. 2011. Magnetic survey at the archaeological site Iepurești (Giurgiu County). In R. Kogălniceanu and A. Morintz (eds.), Tells at the Lower Danube. Muzeul Județean Giurgiu. Archaeological Debates 1. Pelican Publishing House. Giurgiu: 89-96.

Mărgărit M., Ştefan C. E. and Dumitraşcu V. 2013. Industria materiilor dure animale în aşezarea eneolitică de la Cuneşti - "Măgura Cuneştilor" (jud. Călăraşi). In G. Bodi, M. Danu and R. Pîrnău (eds.), De hominum primordiis. Studia in honorem professoris Vasile Chirica. Editura Universităţii "Alexandru Ioan Cuza". Iaşi: 141-168.

Mărgărit M., Parnic V. and Bălăşescu A. in press. Aspects de l'interaction homme-animal en Préhistoire: l'industrie en matières dures animales de l'habitat Gumelniţa de Mă riuţa (département de Călăraşi). Dacia $N$. S. (in press).

Meier J. 2013. More than Fun and Game? An Experimental Study of Worked Bone Astragali from Two Middle Bronze Age Hungarian Sites. In S. O'Connor and A. Choyke (eds.), From These Bare Bones: Raw Materials and the Study of Worked Osseous Objects. Oxbow Books. Oxford: 166-173.

Minniti C., Peyronel L. 2005. Symbolic or functional astragali from tell Mardikh-Ebla (Syria). Archeofauna 14: 7-26.

Monah D., Dumitroaia G., Monah F., Preoteasa C., Munteanu R. and Nicola D. 2003. Poduri - Dealul Ghindaru. O Troie in Subcarpatii Moldovei. Bibliotheca Memoriae Antiquitatis XIII. Constantin Matasă Publishing House. PiatraNeamţ.

Moore K. M.1993. Bone tool technology at Gonur Depe. Information Bulletin (Moscow) 19: 218-227.

Morintz A. S. 2011. Topographic Considerations Regarding the Archaeological Site from Iepureşti, Location 'La 
Izlaz' (Giurgiu County). In S. Mills, P. Mirea (eds.), The Lower Danube in Prehistory: landscape changes and human-environment interactions. Proceedings of the International Conference Alexandria, 3-5 November 2010. Renaissance. Bucureşti: 233-240.

Necrasov 0. 1999. Anexa 3: Expertixa asupra pieselor osoase (arşice)descoperite în staţiunea Cucucteni B1 de la Ghelăieşti - Nedeia. In Ş. Cucoş, Faza Cucuteni B în zona subcarpatică a Moldovei. Bibliotheca Memoriae Antiquitatis VI. Constantin Matasă Publishing House. PiatraNeamţ: 192.

Nica M., Zorzoliu T., Fântâneanu C. and Tănăsescu B. 1977. Cercetări arheologice în tell-ul gumelniţeano-sălcuţean de la Drăgăneşti-Olt, punctul "Corboaica". Campania anului 1955. In Cercetări Arheologice în Aria Nord-Tracă II. Bucureşti: 9-19.

Nicolae C., Nicolae I. and Boroneanț A. 2003. Săpăturile arheologice din situl de la Chitila-Fermă. Campania 2002. Bucureşti. Materiale de Istorie şi Muzeografie XVII: 7281.

Niţu A., Bazarciuc V. 1980. Consideraţii cu privire la ceramica Cucuteni $\mathrm{AB}$ pe baza descoperirilor recente. Arheologia Moldovei IX: 19-60.

Oleniuc C. 2012. Studiul comparativ privind prelucrarea materiei de origine animală în situl arheologic Feteşti, punctul La Schit, jud. Suceava. Materiale şi Cercetări Arheologice (S.N.) VIII: 59-68.

Pandrea S., Vernescu M. and Copilu S. 2002. Însurăţei, jud. Brăila. Popina I. In Cronica Cercetărilor Arheologice din România. Campania 2001. cIMeC - Institutul de Memorie Culturală. Bucureşti: 172-173.

Parnic V., Păun A. 2003-2004. Despre un atelier de prelucrare a osului şi cornului din aşezarea eneolitică de la Măriuţa, jud. Călăraşi. Ialomiţa IV: 53-70.

Perego E. 2010. Magic and Ritual in Iron Age Veneto, Italy. Papers from the Institute of Archaeology 20: 67-96.

Petrescu-Dîmbovița M., Văleanu M.-C. 2004. Cucuteni Cetătuie. Monografie arheologică. Constantin Matasă Publishing House. Piatra-Neamţ.

Petrescu Dîmboviţa M., Florescu M. and Florescu A. C. 1999. Truşeşti. Monografie arheologică. Romanian Academy Publishing House. Iaşi.

Poplin F. 1991. Reflexions sur l'astragale d'or de Varna, les pieds fourchus et la métallisation de l'animal. In J. P. Mohen (ed.), Découverte du metal. Picard. Paris: 31-42.
Popovici D., Buzdugan C. and Alexoaie I. 1992. Aşezarea cucuteniană de la „Balta lui Ciobanu” (com. Roma, jud. Botoşani). Cercetări Arheologice IX: 12-28.

Popovici D., Rialland Y. (eds.) 1996. Viata pe malul Dunării acum 6500 ani. Vivre au bord du Danube il y a 6500 ans. Caisse nationale des monuments historiques et des sites. Paris.

Popovici D., Randoin B., Rialland Y., Voinea V., Vlad F., Bem C. and Haită C. 1998-2000. Les recherches archéologique du tell de Hârşova (dép. de Constantza) $1997-$ 1998. Cercetări Arheologice XI(1): 13-124.

Prummel W., Halici H. and Verbaas A. 2011. The bone and antler tools from the Wijnaldum-Tjitsma terp. Journal of Archaeology in the Low Countries 3(1/2): 65-106.

Reingruber A., Thissen L. 2009. Depending on ${ }^{14} \mathrm{C}$ data: Chronological Frameworks in the Neolithic and Chalcolithic of Southeastern Europe. Radiocarbon 51(2): 751770 .

Reitz E. J., Wing E. S. 2008. Zooarchaeology, Second Edition. Cambridge Manuals in Archaeology. Cambridge University Press. Cambridge.

Riedel A., Tecchiati U. 2001. Gli Astragali dei Corredi Tombali della Necropoli della Prima Età del Ferro di Colombara di Gazzo Veronese. Padusa 37: 149-151.

Schuster C., Morintz A., Popa T. and Gheorghe I. C. 2009. Iepureşti, com. Iepureşti, jud. Giurgiu. Punct: La Izlaz. In Cronica Cercetărilor Arheologice din România. Campania 2008. cIMeC - Institutul de Memorie Culturală Bucureşti: 311.

Schuster C., Morintz A., Dumitraşcu V., Popa T., Kogălniceanu R., Grofu F., Niţă L., Mărgărit M., Markussen C., Crary J. and Coca O. 2010. Iepureşti, com. Iepureşti, jud. Giurgiu. Punct: La Izlaz. In Cronica Cercetărilor Arheologice din România. Campania 2009. cIMeC - Institutul de Memorie Culturală. Bucureşti: 271-272.

Schuster C., Morintz A., Dumitraşcu V., Kogălniceanu R., Niţă L., Mărgărit M., Markussen C., Vornicu M., Gangemi R. and Coca 0. 2011. Iepureşti, com. Iepureşti, jud. Giurgiu. Punct: La Izlaz. In Cronica Cercetărilor Arheologice din România. Campania 2010. cIMeC - Institutul de Memorie Culturală. Bucurevti: 192-193.

Schuster C., Morintz A., Dumitraşcu V., Kogălniceanu R., Ilie A., Niţă L., Mărgărit M. and Haită C. 2012. Iepureşti, com. Iepureşti, jud. Giurgiu. Punct: La Izlaz. In Cronica Cercetărilor Arheologice din România. Campania 2011. cIMeC - Institutul de Memorie Culturală. Bucureşti: 225226. 
Slavchev V. 2010. The Varna Eneolithic Cemetery in the Context of the Late Copper age in the East Balkans. In D. W. Anthony (ed.), The Lost World of Old Europe. The Danube Valley, 5000-3500 BC. Princeton University Press. New York-Priceton-Oxford: 192-210.

Todorova-Simeonova H. 1971. Kusneoeneolitnijat nekropol krai gr. Devnja. Izvestija na Narodnija Muzej Varna 7: 3-40.

Ursulescu N., Boghian D. 1996. Principalele rezultate ale cercetărilor arheologice din aşezarea precucuteniană de la Târgu Frumos (jud. Iaşi) - I. Codrul Cosminului 2(12): $38-72$.

1997-1998. Principalele rezultate ale cercetărilor arheologice din aşezarea precucuteniană de la Târgu Frumos (jud. Iaşi). Codrul Cosminului 3-4 (13-14): 1335 .

Ursulescu N., Ignătescu S. 2003. Preuteşti - Haltă. O aşezare cucuteniană pe Valea Şomuzului Mare. Demiurg. Iaşi.

Ursulescu N., Tencariu A. F., Merlan V., Kogălniceanu R., Chirilă L., Văleanu M., Tencariu L., Ichim A., Cozma M., Ionică D., Solcan L. and Robu I. 2004. Isaiia, com. Răducă neni, jud. Iaşi. Punct: Balta Popii. In Cronica Cercetă rilor Arheologice din România. Campania 2003. cIMeC - Institutul de Memorie Culturală. Bucureşti: 149-153.
Voinea V. 1997. Artifacts made from hard raw material of animal origin, in Archaeological researches at BorduşaniPopină (Ialomiţa County). Preliminary report 1993-1994. Cercetări arheologice X: 96-105.

Voinea V., Neagu G. 2009. Archaeological Research at Hamangia III Settlement from Cheia (2004-2008). Pontica 41: 9-34.

Vornicu A. 2013. Industria materiilor dure animale în cultura Precucuteni. Studiu de caz: artefactele din aşezările de la Isaiia şi Târgu Frumos. Unpublished $\mathrm{PhD}$ thesis. Alexandru Ioan Cuza University. Iaşi.

Vulpe R. 1957. Izvoare, săpăturile din 1936-1948. Romanian Academy Publishing House. Bucureşti.

Walker P. L., Miller K. W. P. and Richman R. 2008. Time, temperature, and oxygen availability: an experimental study of the effects of environmental conditions on the color and organic content of cremated bone. In C. W. Schmidt and S. A. Symes (eds.), The Analysis of Burned Human Remains. Elsevier Press. London: 129-136.

Zidarov P. 2005. Bone artefacts. In I. Merkyte (ed.), Lîga. Copper Age Strategies in Bulgaria. Centre of World Archaeology. Publications 2. Acta Archaeologica 76(1). Blackwell Munksgaard. København: 124-131. 